Article

\title{
Changes in Business Models Caused by Digital Transformation and the COVID-19 Pandemic and Possibilities of Their Measurement-Case Study
}

\author{
Katarina Stalmachova *, Roman Chinoracky (D) and Mariana Strenitzerova $(\mathbb{D}$ \\ Faculty of Operation and Economics of Transport and Communications, University of Žilina, Univerzitná 8215/1, \\ 01026 Zilina, Slovakia; roman.chinoracky@fpedas.uniza.sk (R.C.); mariana.strenitzerova@fpedas.uniza.sk (M.S.) \\ * Correspondence: katarina.stalmachova@fpedas.uniza.sk; Tel.: +421-41-513-31-44
}

Citation: Stalmachova, K.;

Chinoracky, R.; Strenitzerova, M.

Changes in Business Models Caused

by Digital Transformation and the

COVID-19 Pandemic and

Possibilities of Their

Measurement-Case Study.

Sustainability 2022, 14, 127. https://

doi.org/10.3390/su14010127

Academic Editors: Sebastian Saniuk,

Tomasz Rokicki and

Dariusz Milewski

Received: 3 November 2021

Accepted: 20 December 2021

Published: 23 December 2021

Publisher's Note: MDPI stays neutral with regard to jurisdictional claims in published maps and institutional affiliations.

Copyright: () 2021 by the authors. Licensee MDPI, Basel, Switzerland. This article is an open access article distributed under the terms and conditions of the Creative Commons Attribution (CC BY) license (https:/ / creativecommons.org/licenses/by/ $4.0 /)$.

\begin{abstract}
The COVID-19 pandemic has become a key event that has changed our lives. Businesses had to change their daily operations, and working from home has become the norm. Almost everyone who is working from home must use some type of digital technology. It is possible to say that business activities and business models have undergone some form of digital transformation due to the COVID-19 pandemic. Therefore, we chose a company that was affected by these changes, and the main goal of our research was the identification of how the digital transformation that was caused by the pandemic changed the business models of the selected company. Because the analyzed company is operating in the financial sector, this article is a case study. The basic activities and elements of the business models of the selected company, before and during the pandemic, were identified using the Business Model Canvas. We propose a set of key performance indicators (KPIs), based on the Balanced Scorecard, for measuring the newly identified activities and elements of the business models that arose in the company as a result of the COVID-19 pandemic. The knowledge gained in this article shows how the digital transformation changed the functioning of the selected company. The conclusions of this article are mainly for the companies that are considering their own digitalization, which contributes to the long-term sustainability of banking.
\end{abstract}

Keywords: digitalization; digital transformation due to pandemic; sustainable digitalization; Business Model Canvas; Balanced Scorecard; long-term sustainability of banking

\section{Introduction}

The beginning of 2020 was marked by the outbreak of the COVID-19 pandemic. This respiratory disease began to spread around the world. We had to isolate ourselves and reduce almost all of our social and economic activities indefinitely. As a result, most countries had resorted to severe restrictions and closures. Almost all business activities in several sectors were suspended, and millions of people lost their jobs [1]. The outbreak of COVID-19 caused significant changes in the way businesses operate. They had to rethink key elements of their business processes and use of technology to maintain operations. They also had to redefine their work and the role of their offices in creating a safe, productive and enjoyable work environment $[2,3]$.

The design of the future workplace, after the COVID-19 pandemic, is not yet known, but it will inevitably be more inclusive and advanced with regard to the needs of employees and companies. One thing is certain: the creation of a digital strategy and the support of remote work will be essential. Changes will be visible in various activities of businesses' internal processes. For example, if we talk about talent management, which, as a process, aims not only to attract talent but also to develop their skills and knowledge and thus constantly improve their performance and the performance of the entire organization, companies must consider if a personal mentor can do his or her job in the same way online $[4,5]$. 
Research aimed at separating work from the employer's premises and its effects date back to the last century. Authors such as Jack Niles and Allan Toffler predicted the transfer of work to employees' homes, mainly due to the possibility of doing work from home by the use of modern information and communication technologies (ICTs) [6].

The idea of working from home using ICTs was promoted, back in the 1990s, by California-based companies, such as Yahoo, under the name "telecommuting" or "telework". Personal computers and landline phones have replaced long hours of commuting between the home and office. This can be considered as the first generation of teleworking. Laptops, mobile devices and mobile phones enabled work from places other than the home or office. The rapid use of the Internet and downsizing of transistors triggered the development of new ICTs (e.g., smartphones, tablets). Smaller and cheaper devices, such as smartphones and tablets, and the Internet's online network allowed employees to stay connected to their colleagues at any time or place [7].

Remote work is a type of flexible working arrangement. It is work done outside of a traditional office environment, performed by individuals who can be fully remote, perform flexible jobs or be freelancers [8,9]:

- Fully remote employees are employees who work as salaried employees who usually work from home either full-time or part-time for one company with a traditional work environment.

- A flexible job is a type of job that provides some flexibility. Employees with flexible jobs usually work in a regular office, but they have an opportunity to work from home (for example, at least once a week).

- A freelancer is a type of remote worker or remote entrepreneur who usually provides some sort of services.

Remote work might be viewed as advantageous for both employers and employees for a number of reasons. For employees, it can potentially improve work-life balance and reduce the time spent commuting. It can also lead to reduced traffic and congestion, reduced pollution and decrease the energy consumption of offices. It can also create new jobs and attract or retain qualified staff. For employers, one of the main benefits of working from home is, in particular, costs savings. Companies do not need to pay for energy, heating, cooling, building maintenance, security and repairs. A significant reduction also exists in the costs associated with technological infrastructure (telephones and the Internet) in the buildings in which companies carry out their business activities. Further savings are in labor costs (overtime, holiday work) that they would otherwise have to pay. On the other hand, working from home can also have certain disadvantages and poses challenges for employers and employees. It is important to distinguish between personal and professional life. In remote work, employees can be disturbed by childcare or by the household they live in. One disadvantage of working from home is the possibility of distraction in the home environment, which can lead to the postponement of tasks. Social distance- the lack of social contact with co-workers-and fewer financial benefits can be perceived as other disadvantages of working from home for employees $[7,10]$.

Working from home has become a significant phenomenon, and its importance is growing, especially in the times of the pandemic. According to Eurostat, before the pandemic, remote work was done by approximately 3\% of employees in Slovakia. During the years 2019 and 2020, the share of employed persons usually working from home increased from $3.7 \%$ to $5.7 \%$. A similar development can be observed in the surrounding countries, such as the Czech Republic, Hungary, Poland and Austria [11]. Respondents worldwide in 2020 stated that $56 \%$ of them have been working remotely for less than a year. Many employees around the world were required to undertake home office work due to the COVID-19 pandemic. As a result of these circumstances, many of these employees are now identified as remote workers [12]. Telework has been slowly increasing for the past ten years. Since the outbreak of the pandemic, working from home has become the norm for millions of employees in the European Union and worldwide [13,14]. The need to work from home is a key factor of the digital transformation in the past year. Changes in 
the work environment in various companies are advancing at an unprecedented rate [15]. With the development of digital technologies, the classic system of doing business has been disrupted, and many companies have to react to these changes [16].

As business processes change, business models change. The studies by Batocchio, Minatogawa, Anholon [17] and Salgado, Maciel [18] point to the interconnection of strategic management methods, which help to better understand the changes in business models brought about by digital technologies. The studies are theoretical and not applied to a specific case. Therefore, the changes caused by the digital transformation (as a result of the ongoing pandemic) should be analyzed by linking selected methods of strategic management.

\section{Literature Review}

In various studies dedicated to the study of the effects of the use of digital technologies, we meet with the terms digitization, digitalization and digital transformation.

Digitization and digitalization are visually similar terms that are closely associated and often used interchangeably [19]. According to Gartner's Glossary, digitization is the process of the conversion of analog data to the digital form of zeroes and ones. Digitization requires an analog process and turns it into a digital form without any other kind of changes to the process itself [20].

The shift from analog electronic technology to digital technology is the driving force of today's digital revolution. In 1986, 99.2\% of the world's storage capacity was analog. By $2007,94 \%$ of the world's information storage capacity was digitized. According to these facts, we can say that the data that are a part of business processes are often processed through advanced digital technologies. This leads to fundamental changes in business processes [19].

For these changes, we use the term digitalization. According to Gartner's Glossary, digitalization is the use of digital technologies that change a business model and provide new revenue and value-producing opportunities. The process of digitalization transfers a classic business to a digital business or business that uses digital technologies with high intensity [20-23].

Digitalization has three different phases. In the first phase, individual operations or processes are automated. In the second phase, related processes are automated and joined together. In the third-most complex-phase, multiple systems that support business processes and information flows are integrated into various enterprise management systems [24,25].

Another important concept, which is closely related to the use of digital technologies, is digital transformation. Digitization mostly affects one business activity, or a part of it, where its analog form changes to digital. Digitalization, on the other hand, requires the digitization of several business activities but does not entirely lead to the digital transformation of the entire company $[26,27]$. If we talk about the digital transformation of the company, several digitalization projects must be implemented. By digitalization projects, we can understand the integration of digital technologies into all areas of business. In many cases, this means the improvement of the existing and the creation of new business processes and new business models that provide greater value for customers. This change can be accomplished by creating new business models that define the way an organization delivers value to its customers [28,29].

Digital transformation refers to a strategic business transformation, which, at its core, focuses on the customer and equally requires organizational and cultural change, along with implementation of digital technologies. Changes in the organization have led to the interconnection of people and digital technologies, creating a certain socio-technical system (STS), where the integration of digital technologies into social systems represents another evolutionary step of society, and thus of the ways we do business. The creation of STSs results in social networks that have much greater performance potential than social networks that have been built without digital technologies [30]. 
It might be said that we digitize information, digitalize the processes and roles that make up a company's operations and digitally transform the company and its strategy. Digitization and digitalization are about technology; digital transformation is about the customer [27,31]. The focus on the customer can be summed up as the customer-centric adaptation of the businesses strategies, operational settings and technological mix of a company [27].

To realize the full potential of digital transformation, organizations need to measure performance improvements on key performance indicators (KPIs). The importance and use of KPIs may differ in the different phases of digital transformation [32]. Organizational change caused by digital transformation can lead to improved performance. Cultural change represents a shift towards more agile and intelligent ways of doing business based on the use of digital technologies, such as advanced software-based analytical tools and artificial intelligence (AI) $[33,34]$. Companies' efforts for digital transformation have largely begun and are becoming wider and deeper. By 2023, digitally transformed organizations are expected to contribute more than half of the global GDP [29].

It is also important to know the adaptation of the population to the changes caused by digital transformation. The long-term mapping of the use of digital technologies by the citizens of Slovakia has shown that the proportion of people who know how to use digital technologies, but with certain problems, does not increase. On the contrary, the share of those who announce that they are working with digital technologies is slowly rising. Such change must be seen in particular regarding the increased external pressure of society on digital skills. Many employees are worried about how digital transformation will influence their job if they do not have the right digital skills. [35] Because of the growing amount of information on the Internet and people's increasing dependence on information, digital skills should be considered as a vital resource in contemporary society [36]. The digital transformation takes time, and the human workforce can feel "in shadow" of new technologies. Modernization in the workplace, career progression and changes in job classification are the reasons why employees have to adapt to modern technologies [16,35]. It might be said that the emergence of digital technologies, digital platforms and digital infrastructures significantly transformed innovation and entrepreneurship [37]. Digital technologies provide more information, more computing, communication and connectivity; therefore, they enable new forms of collaboration [36,38-40].

The COVID-19 pandemic has implied significant changes in the STS and in the ways organizations operate [41]. During the pandemic, people do not work with digital technologies in the workplace but use them remotely from home. Digital technologies allowed work to continue despite strict measures and restrictions in society. They helped to mitigate the economic consequences of the pandemic on the economy. Many companies, using the digital technologies, adapted and overcame the current situation and made work easier for employees. They have allowed people to connect with friends, family, colleagues or superiors at any time [42-44].

The digital transformation is a paradigm shift that fundamentally strengthens the way companies do business and maintain their competitiveness and relationship with customers. In all industries, the question is not whether disruption will occur but when and how $[45,46]$.

According to a Microsoft survey, which concerned financial services, the respondents said the digital transformation is an opportunity for growth, not a threat. The most common motivations for the adoption of digital technologies were to gain new customers, reduce overall costs, increase customer satisfaction, improve the quality of products and services and develop new ones. Thanks to new technologies, most organizations have either set up digital intrusion teams or are in the process of implementing them. Indeed, $34 \%$ of financial sector institutions have a specialized digital transformation team, and 19\% do not but are currently building one. The financial services sector is very competitive, and customers are increasingly demanding, so technology is a means of greater flexibility that helps maintain competitive prices $[47,48]$. 
The pandemic that began almost two years ago and the digital transformation that is associated with it has affected various spheres of our everyday lives. The same applies for all businesses and, particularly, businesses operating in the financial sector. Overall, the consequences of the pandemic and digital transformation are not so easily quantifiable, and it is necessary to understand the changes that were caused by these phenomena. It is also true that the changes caused by the digital transformation in the financial sector are behind the emergence of paperless banking. When banks in the financial sector digitally transform and operate paperless, they ensure the long-term sustainability of environmentally friendly banking.

Therefore, the aim of this article is to demonstrate the changes caused by the COVID-19 pandemic that caused the digital transformation of businesses. The changes relate to the business models. The efficiency and performance of the business models need to be measured and evaluated. Thus, another aim of this article is in the proposition of a set of KPIs that would measure the consequences of the digital transformation.

\section{Materials and Methods}

For the purpose of achieving the goals of this article, we carried out primary and secondary research. The research took place in late June and early August 2021. Overview of the research activities is stated in Table 1. Column named "duration" specifies the duration in units of measure, which are days. As a part of the primary research, we contacted one of the banking managers working at the bank's headquarters in Bratislava, Slovakia. Bank manager provided us with valuable information, which the manager obtained from other managers and employees of this bank. Employees of the bank conducted brainstorming, according to which their experiences and suggestions regarding the changes of the bank's business models were summed up. The bank's employees wanted their names to be anonymous. Given that much of the information provided to us by the bank's employees was based on publicly available sources (articles and bank's annual reports), our claims were based on these sources. At the same time, we supplemented the information provided to us by the bank's employees with the information that we obtained during the secondary research, during which we analyzed already mentioned articles and bank's annual reports in more depth.

Table 1. Overview of research activities.

\begin{tabular}{cccc}
\hline Activity & Start & End & Duration \\
\hline Conceptualization of literature review & 28 May 2021 & 18 June 2021 & 21 \\
Contacting and communication with the & 18 June 2021 & 24 July 2021 & 36 \\
manager & 25 June 2021 & 24 July 2021 & 29 \\
Analysis of provided information & 2 July 2021 & 24 July 2021 & 22 \\
Analysis of publicly available sources & 25 July 2021 & 29 July 2021 & 4 \\
Creation of BMC before the pandemic & 30 July 2021 & 6 August 2021 & 7 \\
Creation of BMC during the pandemic & 7 August 2021 & 14 August 2021 & 7 \\
Summarizing the identified changes & 15 August 2021 & 18 August 2021 & 3 \\
and their evaluating & 19 August 2021 & 23 August 2021 & 4 \\
Integration of BSC into BMC & &
\end{tabular}

The article focuses on the analysis of the business models of a selected bank before and during the COVID-19 pandemic. For this purpose, we used the management tool of Business Model Canvas (BMC). Subsequently, according to the findings of the analysis, we provide a set of KPIs with which a bank can measure the changes that were caused by the digital transformation that was driven by the COVID-19 pandemic. The KPIs are grouped according the tool of Balanced Scorecard (BSC). The theoretical framework regarding both tools is stated in the subchapters of this chapter.

The selected institution for which the analysis was performed and the BMC was constructed is UniCredit Bank. UniCredit Bank is a part of UniCredit Group and is an 
Italian banking and financial services company with a strong position in Western and Eastern Europe. Its headquarters are in Porta Nuova, Milan. The company was founded in 1998 by a merger of several banking groups (Unicredito and Credito Italiano) [49].

UniCredit Bank Czech Republic and Slovakia, a regional branch of UniCredit Bank, was established on 1 December 2013. UniCredit Bank is a successful pan-European commercial bank with a full-fledged company and investment banking, which, within its unique business networks in Western, Central and Eastern Europe, offers services to a large and growing client base. Through a worldwide network of approximately 6300 branches and more than 119,000 employees, clients have access to the international markets. UniCredit Bank's services are present in almost 50 countries around the world and are already used by more than 40 million clients [50]. UniCredit's vision for the future is to improve the customer experience as much as possible. They are combining total transparency with intelligent systems and digital payment methods. The bank does not change its products, but it changes the ways the products are offered to the customers [51].

To achieve the goal of this article, we also formulated several research questions:

- How did the COVID-19 pandemic change UniCredit's business models?

- How did the KPIs based on the BSC have to be changed as a consequence of the amendments in business model?

- How can the two theoretical frameworks (Business Model Canvas and Balanced Scorecard) be integrated for gaining a deeper understanding of the bank's operation?

Answers to the research questions are in the "Results" chapter of the article. At the same time, the solution of the third research question represents a new perspective for the interconnection of two methods of strategic management in the conditions of the banking sector. The original connection between the two models is based on the scientific works of Batocchio, Salgado [17] and Machado, Maciel [18]. A new perspective for the interconnection of the BMC and BSC is, in essence, a research gap. The previous study of Batocchio, Salgado, Machado and Maciel provides a theoretical framework for the development of the methodology. Our case study goes beyond this and illustrates a practical connection of both methods. The practical connection between the two methods lies in the specific design of the KPIs (categorized according to the BSC perspectives) concerning the changes identified by the BMC.

In addition to the primary and secondary research and formulated research questions, our research can be described as qualitative research because the information provided by the BMC and BSC is not numerically expressed. The method of qualitative research we used is a case study. The reason for using the case study is in the fact that we based our findings on the analysis of one selected object of research, which is UniCredit Bank. The application of the acquired knowledge helps us to understand similar cases that may occur with objects that perform the same or similar activity under the same or similar conditions.

\subsection{Business Model Canvas}

If we want to talk about how digital transformation affects the business processes (caused by the COVID-19 pandemic), a suitable tool for such an oriented comparison is the $\mathrm{BMC}$. The main objective of the BMC is to help companies move beyond product-centric thinking and towards business model thinking, which helps companies visualize and understand the key areas of their business [52]. The BMC is essentially an organized way to layout assumptions about not only the key resources and key activities of a business' value chain but also business' value proposition, customer relationships, channels, customer segments, cost structures and revenue streams [53].

This means that the overall BMC framework is divided into nine building blocks (see Figure 1) [54]: 


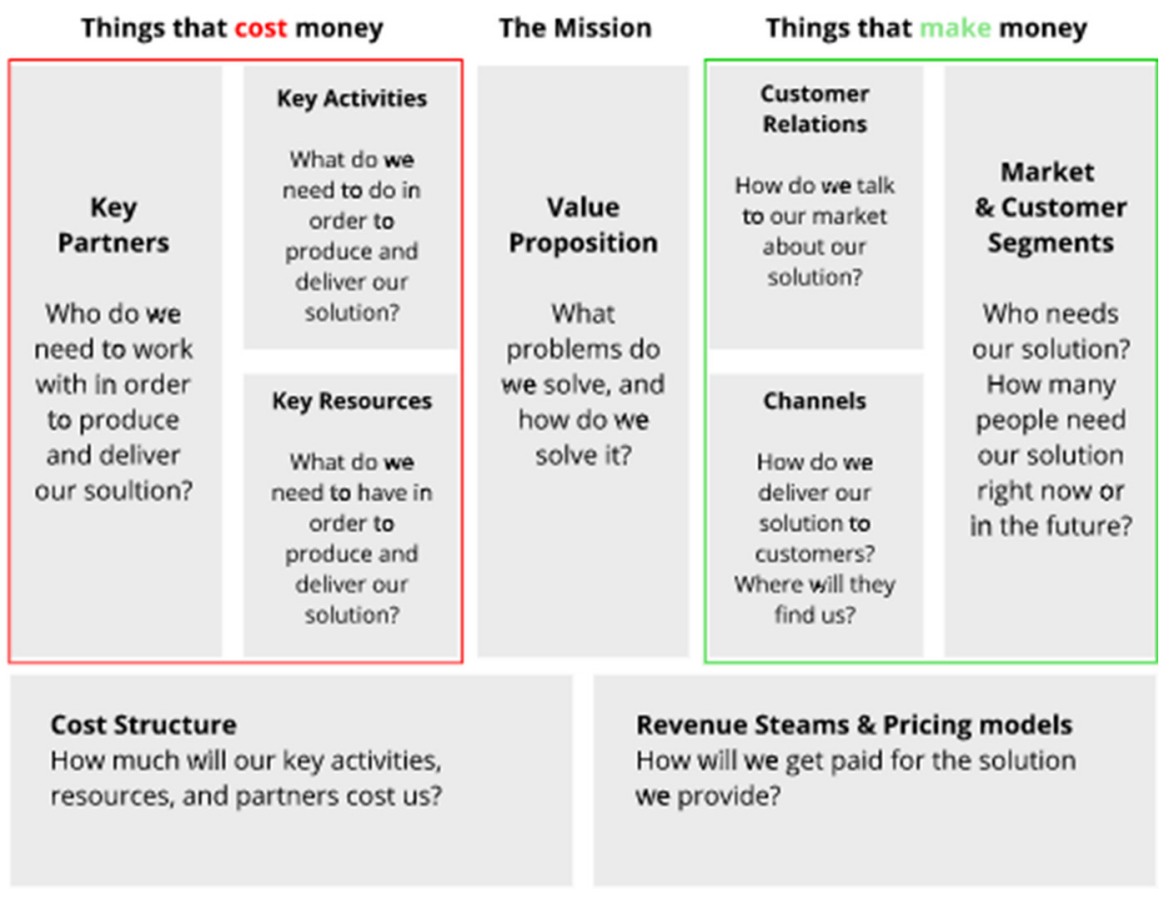

Figure 1. Business Model Canvas. Source: [54].

Based on Figure 1, we can characterize its individual parts (business blocks) from its center to the parts that "make" or "cost" money as [54,55]:

Value proposition, as a key block of the BMC or a mission of business, is a description of the company's products and services in terms of how they will solve customer problems and what customers will gain from them. It is the core of the business intention of any company. Knowing what value a company brings for its customers, any company can distinguish itself from its competitors.

Key partners are other entities that will help a company run a business and minimize risks. These can be business partners or suppliers.

Key activities are activities that make business a reality. It is not just about production. Important activities that are part of business models, for example, include problem-solving approaches, networking and product quality. Knowing which key activities are essential, companies can better understand the added value they offer for their customers.

Key resources are, in essence, materials that serve the company to carry out any of its key activities. A company's key resources can be categorized into four groups: physical (buildings, equipment), intellectual (know-how, patents, knowledge), financial (funds and sources of income) and human resources (employees and external partners).

Caring for key partners, implementation of key activities and securing key resources costs companies money.

Customer relations define how a company builds a long-term customer relationship. With a broader customer base, it is necessary to segment current or potential customers to different target groups. Each segment has its own needs. Therefore, it is important to forecast needs of each target groups of customers. Fulfilling customers' needs may result in good customer relations in the future. Companies usually try to build a community around its products or services.

Channels define how a product or service will reach customers. Are products or services distributed to customers through a brick-and-mortar store, virtual store or franchise? It is essential to know this because distribution channels affect a large part of the company's organizational structure.

Market and customer segments allow companies to divide customers according to the value they bring to the company. As a business provides different products to its customers, it possibly differentiates its customer base into specific customer groups or 
customer segments. Based on the segmentation, products can be adapted according to the needs of different customer segments. Greater customer satisfaction can be achieved, which, in turn, can lead to a better value proposition.

Good customer relations, knowledge about customer segments and optimization of distribution and communication channels can be a source of income.

Cost structure helps companies gain financial health overview. Most common cost items that companies analyze include various sub-categories of constant and variable costs. Costs usually have to be optimized when it is obvious that they exceed revenue.

Revenue streams and pricing models provide insight into a company's revenue models. Revenue streams are often cost drivers. They answer basic questions: how many customers does a company need on an annual basis to generate a profit? How much revenue does it need to generate to gain a profit?

\subsection{Balanced Scorecard}

If we know what activities have undergone a digital transformation, we may ask ourselves: what is the success of this transformation? The answer to this question is in the examination of selected KPIs. Digital transformation can take place across the entire company. Simple measurements cannot capture its overall success (or failure). Therefore, it is appropriate to use a multi-dimensional framework for measuring business performance. Such a multi-dimensional framework that was suitable for the purposes of our research was the BSC [56,57]. The Balanced Scorecard enables the selected company to understand which KPIs should be measured in relation to the company's set goals. The name "Balanced Scorecard" comes from the idea of looking at strategic measures in addition to traditional financial measures to get a more "balanced" view of performance $[58,59]$.

The subject of our research was digital transformation. Therefore, for the purposes of this article, model business goals and KPIs were created. These goals and KPIs can help measure the success of the digital transformation of the selected company.

The BSC suggests that an organization should be examined from four different perspectives to help develop objectives, measures (KPIs), targets and initiatives relative to those views (Figure 2) [60]:

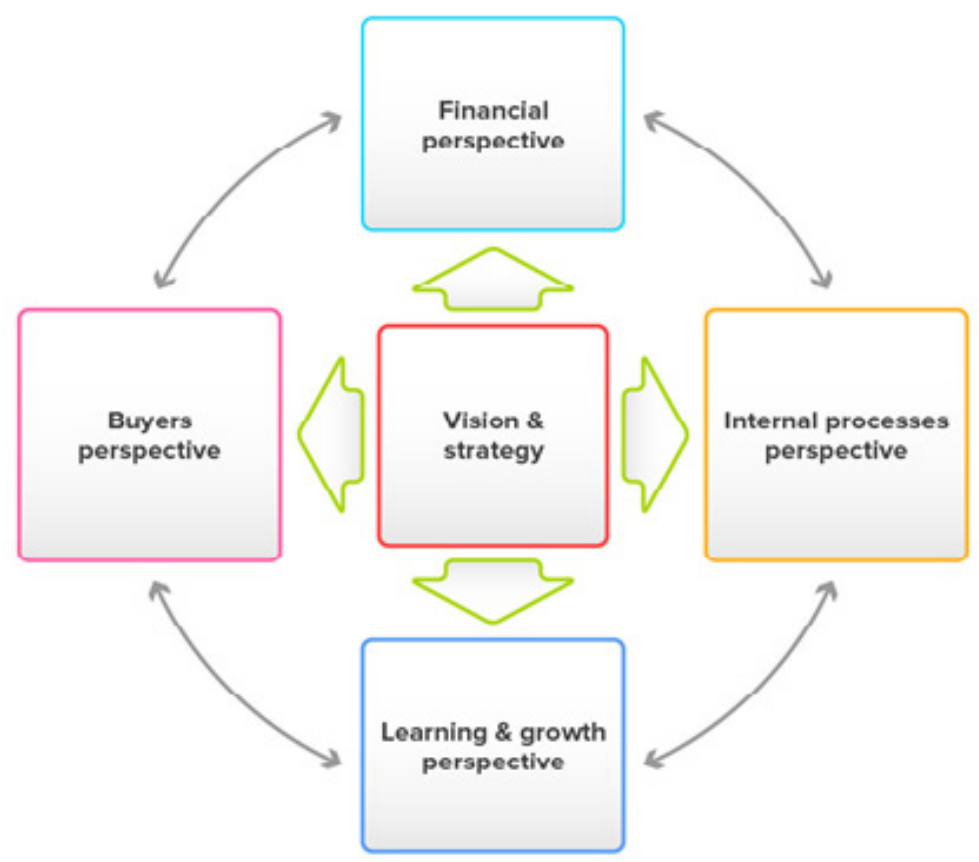

Figure 2. Balanced Scorecard. Source: [60,61].

According to sources $[46,60,62,63]$, perspectives of BCS are summarized in Table 2. 
Table 2. Perspectives of BSC.

\begin{tabular}{|c|c|c|}
\hline Perspective & Description & KPIs \\
\hline Financial perspective & $\begin{array}{l}\text { Views an organization's financial } \\
\text { performance and the use of financial } \\
\text { resources. Financial perspective } \\
\text { encourages the identification of a few } \\
\text { relevant high-level financial } \\
\text { measures. }\end{array}$ & $\begin{array}{l}\text { Cash flow, sales growth, } \\
\text { operating income, return on } \\
\text { equity }\end{array}$ \\
\hline $\begin{array}{l}\text { Buyers (customers) } \\
\text { perspective }\end{array}$ & $\begin{array}{l}\text { Views organizational performance } \\
\text { from the perspective of the customer } \\
\text { or key stakeholders a company is } \\
\text { designed to serve. Buyers (or } \\
\text { customers) perspective helps identify } \\
\text { the measures that help us understand } \\
\text { what is important for customers or } \\
\text { stakeholders. }\end{array}$ & $\begin{array}{l}\text { Percent of sales from new } \\
\text { products, on time delivery, } \\
\text { share of important customers' } \\
\text { purchases, ranking by } \\
\text { important customers. }\end{array}$ \\
\hline $\begin{array}{l}\text { Internal processes } \\
\text { perspective }\end{array}$ & $\begin{array}{l}\text { Views the quality and efficiency of } \\
\text { company's internal performance that } \\
\text { are key for company's successful } \\
\text { outside performance. Internal } \\
\text { processes perspective identifies the } \\
\text { measures that tell us what must we } \\
\text { excel at. }\end{array}$ & $\begin{array}{l}\text { Cycle time, unit cost, yield, } \\
\text { new product introductions. }\end{array}$ \\
\hline $\begin{array}{l}\text { Learning \& Growth } \\
\text { perspective }\end{array}$ & $\begin{array}{l}\text { Views human capital, infrastructure, } \\
\text { technology, culture as key factors that } \\
\text { can impact businesses performance. } \\
\text { Learning \& Growth perspective helps } \\
\text { us understand how we can continue } \\
\text { to improve, create value and innovate } \\
\text { business processes. }\end{array}$ & $\begin{array}{l}\text { Time to develop a new } \\
\text { generation of products, life } \\
\text { cycle to product maturity, time } \\
\text { to market versus competition }\end{array}$ \\
\hline
\end{tabular}

\section{Results}

\subsection{Business Models of UniCredit Bank before and during the COVID-19 Pandemic}

The value proposition is the building block that is at the center of the BMC (Table 3). Value propositions might be essential not only for customers but also for society, employees or shareholders. For customers, it might be valuable that UniCredit Bank supports individual clients and European corporate mid-range clients, which form the basic pillar of the European segment economy, as the second-largest corporate creditor in continental Europe. UniCredit Bank also continuously improves the client experience and strengthens the bank's position in the Czech and Slovak markets. This is due to the bank's emphasis on solving the needs of its clients by further simplification of its internal processes and corporate digitalization [64]. UniCredit Bank is also interested in environmental protection and tries to perform various activities that help to reduce its direct impact on the environment. For example, the bank has removed all disposable plastics from their headquarters. They also regularly address social needs, support education and research and sponsor charitable events [64]. Value proposition can be seen in relation to employees or potential employees, i.e., jobseekers at UniCredit Bank. The focus on digitalizing key HR processes means faster communication with candidates and internally between employees [64]. Shareholders also have the opportunity to participate in an open dialogue with the management of UniCredit Bank and thus participate in decision-making. UniCredit is a public company with free capital, equal to $100 \%$ of the outstanding shares. UniCredit's shareholders are institutional shareholders, retail shareholders, sovereign wealth funds, foundations and others from the United States, United Kingdom, Europe and the rest of the world [65]. 
Table 3. Business models of UniCredit Bank before COVID-19 pandemic.

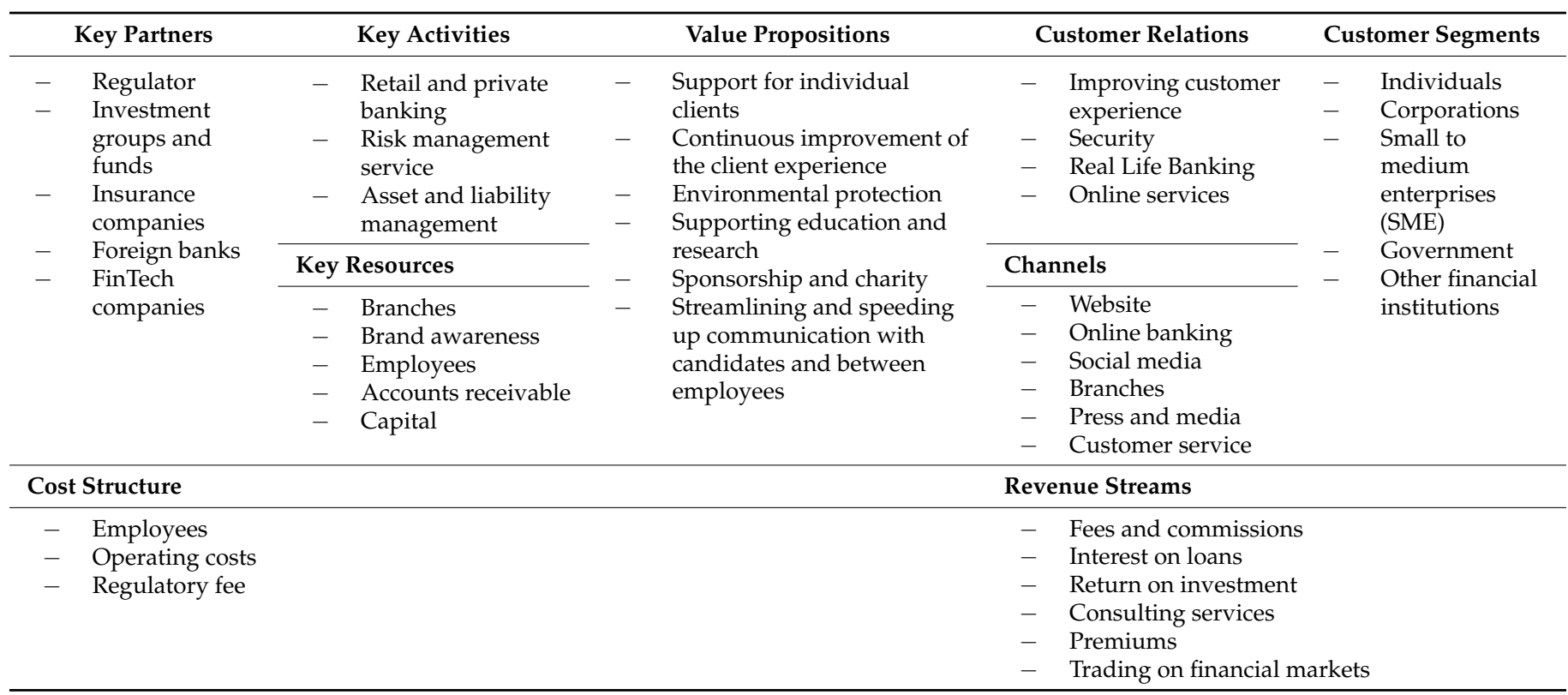

The key partners for UniCredit Bank can be divided into several groups. The first group is the controller (regulator). At the European level, this group includes the European Central Bank, which supervises Euro area banks [66]. At the national level, the regulator of UniCredit Bank is the National Bank of Slovakia, which provides the general rules for supervision of the financial market in the area of banking, capital market, insurance and pension savings. The aim of financial market supervision is to contribute to the stabilization of the financial market as a whole because they need to have safe and sound functioning that preserves its credibility, protects financial consumers, other clients and respects competition rules $[67,68]$.

The government as a regulator regulates banks through Act No. 483/2001 on banks and on amendments to certain acts, relationships related to the establishment, organization, management, entrepreneurship and dissolution of banks in Slovakia as well as certain relationships relating to the operation of foreign banks in Slovakia for the regulation and control of banks, branches of foreign banks and others entities. The aim of state regulation is to ensure the safe operation of the banking system [69].

UniCredit Bank also has long-term cooperation with selected companies for various segments of its clients. These key partners are various investment groups, funds and insurance companies. When choosing partners, UniCredit Bank considers several criteria. For example, a key partner for a bank has to be a leader in asset management, offer a wide range of funds covering most asset classes and have funds with best-in-class potential [70]. Within the UniCredit Group, banks in the individual countries that are part of the group cooperate. Clients can also control their finances abroad through a private banker in Slovakia. Cooperating foreign banks include, for example, Schoellerbank in Austria, UniCredit Bank AG Munich or Bank Austria [71]. In cooperation with FinTech Companies, UniCredit Bank introduced Apple Pay and Google Pay mobile payments for VISA and Mastercard payment cards in 2019 [64].

For key activities, UniCredit Bank realizes retail and private banking. In cooperation with strategic partners, the bank is increasingly focused on investment products and bancassurance. This means that UniCredit is taking care of the existing client portfolios and at the same time acquires new private banking clients by the expansion of its range of investment solutions [64].

As part of its risk management, the bank rigorously monitors and adheres to the sets of parameters that make up its risk appetite framework. The bank manages its credit risk at 
the level of the individual business transactions as well as at the level of the whole portfolio in accordance with basic principles defined in the bank's credit policy in order to comply with the risk parameters set out in the credit strategy for the year in question. The bank provides services in the area of security projects aimed at reducing risk and preventing leaks and data protection. The bank regularly monitors and reports on the regulatory liquidity ratio LCR (liquidity coverage ratio) and planned NSFR (net stable funding ratio) indicator. The sufficient distance of these indicators from the minimum is evidence of a strong and sustainable level of liquidity of the bank [64].

To sum it up, the UniCredit's activities are performed on the basis of a single banking license, on the basis of which the bank may perform activities for both individuals and legal entities, such as [72]:

- Accepting deposits and other repayable resources;

- Providing loans;

- Financial leasing;

- Money transfer services;

- Issuing and managing funds;

- Guarantees and promises;

- Trading on its own account or client account;

- Participation in securities issues;

- Advising companies on capital structure, industry strategy or money market intermediation;

- Manage portfolio;

- Custody and administration of securities;

- Credit reference services;

- $\quad$ Safe custody services;

- Issuing electronic money;

- $\quad$ The provision of investment services to a specified extent.

UniCredit Bank's key resources are needed to carry out key activities and can be divided into several categories: financial resources, intellectual, human and physical resources. UniCredit's branch network is a physical resource consisting of 126 branches and, together with the franchise distribution network, consists of a total of 178 branches. In order to maximize customer satisfaction, UniCredit Bank is constantly reconstructing and modernizing many branches. In addition to branches, ATMs can also be considered a key physical source of the bank [64]. The key intellectual resource for UniCredit Bank is brand awareness. UniCredit Bank can be easily identified by customers by its corporate logo: a white number one in the middle of a red sphere. Through its logo, UniCredit strives to communicate to customers the idea that the focus is on the customer. Red sphere expresses dynamism, reliability and a global approach. The white number one in the middle of the sphere represents unique strength and leadership [73,74]. One of the most important resources of UniCredit Bank is its employees. UniCredit Bank promotes a working culture of ethics, respect, diversity, inclusion, friendly team atmosphere, self-realization, positivity, recognition and career development of its employees. Work-life balance is also important. The bank pays maximum attention to the recruitment, remuneration, training and development of its employees in the fields of professional knowledge and communication skills [64]. From this point of view, knowledge management plays a key role. In particular, a key for UniCredit is knowledge sharing-a centralized, easily accessible knowledge base for all employees at all levels.

In general, banks have two sources of financing: capital and debt. Debt is money that a bank has borrowed from its creditors and must repay. These can be client deposits, issued debt securities or borrowings. Capital represents money that a bank has received from its shareholders and other investors and any profit that it has made but not paid out [75].

In the area of customer relations, UniCredit Bank is constantly striving to improve the customer experience as well as increasing process efficiency through automation and digitalization. In the era of unprecedented change, customers are looking for companies 
they can trust. Therefore, UniCredit Bank promises to their customers "Real Life Banking" and provides relevant solutions to real needs, simply and efficiently [73].

They also offer online banking services for customers. In 2019, online banking was transferred to a more modern infrastructure for retail clients, which enables the development of applications in accordance with current trends and client requirements. Corporate clients have the opportunity to use Business Smart Banking [64].

At the same time, UniCredit Bank implements security measures through payment gateways aimed at reducing risk and preventing data leakage and protection when customers pay online [64,76]. All data sent from the contact forms on the UniCredit Bank's website are secured by SSL 3.0 technology. This technology ensures encrypted data transmission between the customer's computer and UniCredit's web servers. Security certification of UniCredit Bank was issued by a globally recognized certification authority VeriSign, Inc. [77].

Channels are contact points that allow customers to connect with the company. They play an important role in raising customers' awareness of a product or service. Channels can also be used to provide customers with a way to purchase products or services and post-purchase support.

UniCredit Bank communicates with its customers through its website, at branches, through the press and the media. They can also carry out activities themselves through online banking. UniCredit Bank is active on social media and presents the news to its customers on YouTube and Twitter. If customers have any questions, they can contact the bank through customer service [78-80].

The cost structure section of the BMC, in the case of UniCredit Bank, includes staff costs, such as salaries, bonuses, levies, taxes, social costs (for example, employee care). The bank also incurs operating expenses to carry out its activities, such as rent and maintenance of buildings, IT costs, advertising and marketing costs, material consumption, audit and advisory services, administrative and logistical services, deposit and business insurance and other services [64]. In addition to operating costs, the bank pays a regulatory fee. The annual contributions are required to be paid to the National Bank of Slovakia by a supervised entity that has obtained a permit or other authorization to perform activities in the area of the financial market. The annual contributions must also be paid as a contributor by the supervised entity, which has its registered office outside the territory of the Slovak Republic and which is entitled to create or manage funds through the branch or even without establishing a branch [81].

Revenues streams are the sources from which a bank generates money by selling its product or service to the customers. For UniCredit Bank, revenues include, for example, fees and commissions interest on loans, return on investments, rental income and rental income from real estate investments or income related to leasing [64,82]. UniCredit Bank can also provide its clients with consulting services for a given fee. Other income includes premiums or revenues trading on financial markets [83,84].

Taking into account the findings concerning the bank's business models before the pandemic, Table 4 provides us with information on which business models of UniCredit Bank have undergone changes caused by digital transformation. Key changes are highlighted (green text in bold).

If we look at how UniCredit Bank's business models have changed as a result of the COVID-19 pandemic and digital transformation, the biggest change can be seen in the sections of value propositions, customer relations and channels.

Due to the pandemic, UniCredit digitized some of its products and services and also introduced new products and activities, which will bring benefits, especially to customers. In this area are the most significant leasing activities using a dynamic electronic signature on tablets and online completion consumer onboarding. UniCredit is also preparing a digitized mortgage application process for clients and third parties [85]. The digitalization of activities and products does not require the creation of physical records. The bank does 
not consume paper and thus contributes to environmental protection and its long-term sustainability.

Table 4. Business models of UniCredit Bank during COVID-19 pandemic.

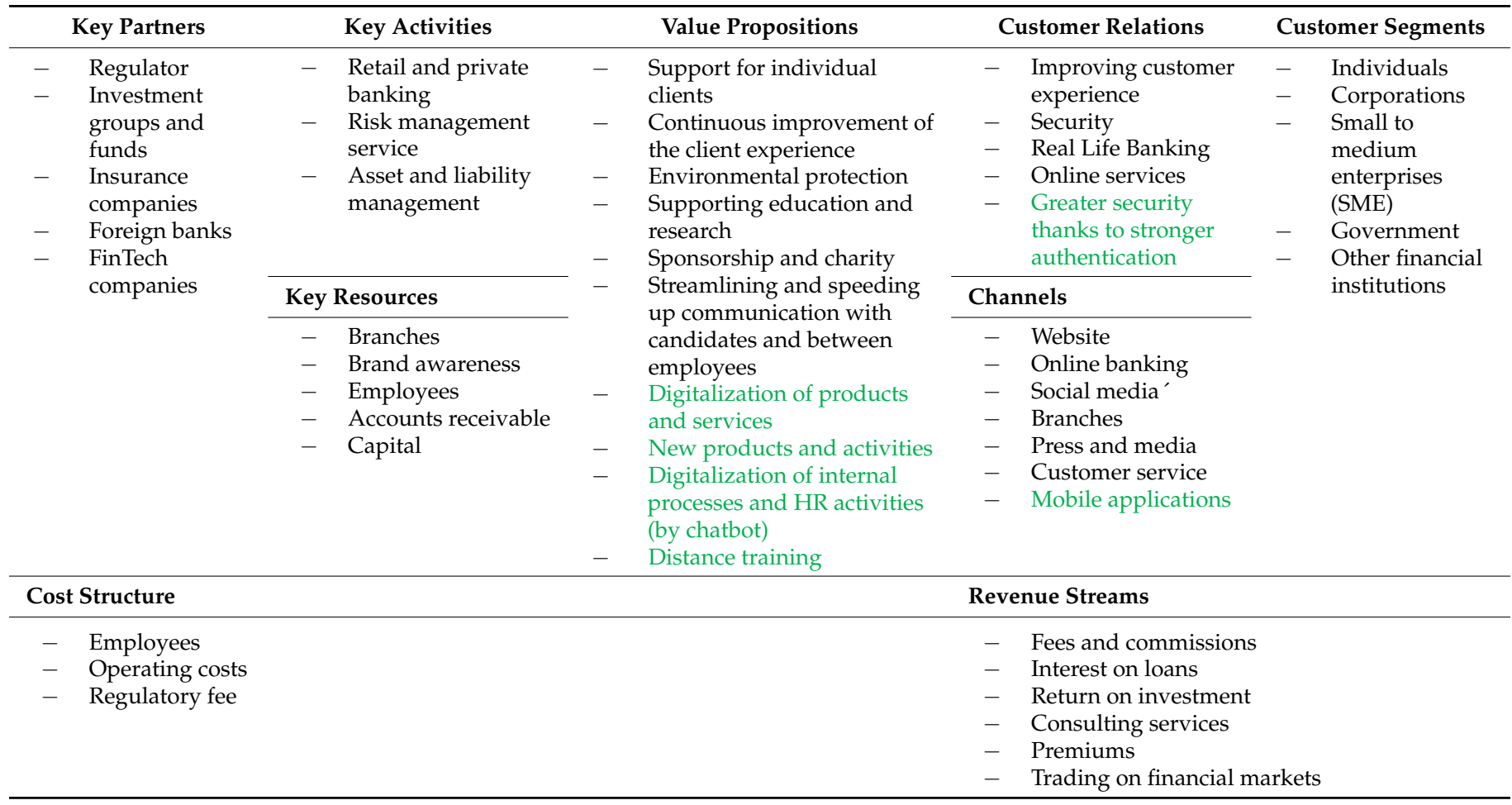

As part of the safety and health of employees during the COVID-19 pandemic, employees were allowed to work from home in order to continue UniCredit's business activities and provide services to customers. UniCredit has provided its employees with new laptops so that they can work remotely. In connection with the home office, it was also necessary to introduce distance training for employees, where they could learn how to better lead teams and manage the way of teleworking. Employees were also provided with a practical guide to better understand how they can work from home. In the field of human resources management, the bank started to use chatbots in communication with potential job seekers [85].

During the pandemic, UniCredit Bank launched an innovative Smart Banking application for mobile banking that is publicly available for download [78,85]. Thanks to this application, clients can conveniently manage their bank accounts from anywhere without having to visit a physical branch. The bank also introduced modern payment methods Apple and Google Pay, which are very popular among clients and through which millions of transactions are processed. The bank is switching to new modern VISA payment cards and further innovates its digital services [85].

As a result of the pandemic, UniCredit also proceeded to digitize its internal processes. Digitization occurred in the: approval of credit cases and simplification of credit checks, digital document processing and automated preparation of contractual documentation [85]. The digitalization of internal processes again has reduced the amount of used paper. This reduction contributed to the protection of the environment and the long-term sustainability of the bank.

Within customer protection, UniCredit Bank unilaterally adjusted the purchase authentication process via the Internet in accordance with the new European Union Payments Directive (PSD2). This Payment Directive states that two authentication elements should be used in the case of online banking card transactions. Under this Directive, from 1 January 2021, the banks must require strong customer authentication if the acquirer operates 
in the European Economic Area. The exemption can only be used in specific cases (for example, small volume transactions or if you have already registered your bank card for the acquirer).

During the pandemic, the need for more secure transactions has grown. UniCredit Bank has adapted and introduced 3D secure technology for its online banking. The bank's clients no longer have to rewrite any codes from the SMS. Now, they authorize payments by payment card in online stores using notifications in the Smart Banking or Smart Key applications [76].

\subsection{Structure of KPIs Related to the Digital Transformation of UniCredit Bank}

Digitization appeared in UniCredit Bank even before the pandemic in areas of channels, value proposition and customer relations. The bank used digital channels (online banking and social media) to connect with customers. Before the pandemic, the bank sought to improve the customer experience and customer relations by ensuring the safety of its online services.

During the pandemic, some areas experienced changes in connection with the digitalization of UniCredit business models. In the value proposition, further progress can be seen in streamlining communication either between employees or job seekers, where the bank started using chatbots. At the same time, in this area, the bank digitized some products and services so that the clients do not have to physically visit the branch. For this reason, the bank also introduced a mobile application to give clients faster access to its services and strengthen the security, which is key for customers in the times of a pandemic.

If we take into account these findings, it is important for the company to understand the impact of these changes by gaining knowledge that can be obtained from the measurements of the group of selected KPIs, which are categorized into BSC's four perspectives. To better understand which component of the BMC model is linked with each BSC perspective, we made a framework that highlights the connection between both tools (Table 5).

Table 5. Integration of BSC perspectives into BMC.

\begin{tabular}{|c|c|c|c|c|}
\hline Key Partners & Key Activities & Value Propositions & Customer Relations & Customer Segments \\
\hline $\begin{array}{l}\text { Internal Processes } \\
\text { Perspective }\end{array}$ & $\begin{array}{l}\text { Internal Processes } \\
\text { Perspective }\end{array}$ & $\begin{array}{l}\text { Customers } \\
\text { Perspective }\end{array}$ & $\begin{array}{l}\text { Customers } \\
\text { Perspective }\end{array}$ & $\begin{array}{l}\text { Customers } \\
\text { Perspective }\end{array}$ \\
\hline & $\begin{array}{l}\text { Learning \& Growth } \\
\text { Perspective }\end{array}$ & $\begin{array}{l}\text { Internal Processes } \\
\text { Perspective }\end{array}$ & $\begin{array}{l}\text { Internal Processes } \\
\text { Perspective }\end{array}$ & \\
\hline & Key Resources & & Channels & \\
\hline & $\begin{array}{l}\text { Learning \& Growth } \\
\text { Perspective }\end{array}$ & & $\begin{array}{l}\text { Internal Processes } \\
\text { Perspective }\end{array}$ & \\
\hline & & & $\begin{array}{l}\text { Customers } \\
\text { Perspective }\end{array}$ & \\
\hline Cost Structure & & & Revenue Streams & \\
\hline $\begin{array}{l}\text { Internal Processes } \\
\text { Perspective }\end{array}$ & $\begin{array}{l}\text { Financial } \\
\text { Perspective }\end{array}$ & $\begin{array}{l}\text { Learning \& Growth } \\
\text { Perspective }\end{array}$ & $\begin{array}{l}\text { Internal Processes } \\
\text { Perspective }\end{array}$ & $\begin{array}{l}\text { Financial } \\
\text { Perspective }\end{array}$ \\
\hline
\end{tabular}

Financial goals usually relate to profitability [60]. These goals can be measured by operating income or return on capital. In order to achieve the bank's financial strategic goals, it is necessary to define the current business model of cost structure and revenue streams and set strategic goals and KPIs based on this model.

In order to achieve strategic goals in relation to customers, it is necessary for the bank to identify current relationships with its customers and to know their segmentation. 
However, the customer perspective should also include specific value proposition measures that the company will deliver to customers in targeted market segments [60].

From an internal process perspective, critical internal processes should be identified in which the organization must excel: deliver value proposals that attract and retain customers in target market segments, and meet shareholder expectations with excellent financial returns. Internal process measures focus on internal processes that will have the greatest impact on customer satisfaction and the achievement of the organization's financial goals [60]. In order to maintain a competitive advantage, it is necessary to monitor and innovate key activities within the BMC, and, based on this, it is necessary to innovate strategic goals in this area and monitor their achievement. It is also important to know the channels through which the customer will be informed about the activities and products and services of the bank. Therefore, it is necessary to constantly monitor existing channels and determine their effectiveness.

Organizational learning and growth come from these key sources: people, systems and organizational procedures [60]. In order to meet the strategic goals of learning and growth, it is, therefore, necessary to first define key activities and then key resources.

Taking into account the findings in UniCredit's business models before and during the COVID-19 pandemic, it can be stated that digital transformation plays an important role, which corresponds to the growing demand for the simplification and optimization of UniCredit's processes. Not all parts of the business models of UniCredit Bank were affected by the digitalization that was caused by the pandemic. However, digital transformation is a trend that will move forward in the future. Thus, it is necessary to have an overview of the changes that can occur in all the business models. In connection with this, UniCredit Bank states its vision as a continuation of the use of technologies that accelerate digital transformation and long-distance banking with regard to sustainability. Ethics and respect are corporate values that apply throughout the UniCredit Group and that define the corporate culture of its Slovak branch. With an emphasis on business sustainability, they are guided by the principle of doing the "right thing" [76].

According to UniCredit's vision, or the strategy that is derived from this vision, it is possible to set goals. By fulfilling these goals, UniCredit Bank will be able to achieve this vision. In this article, we propose goals that are in the context of UniCredit Bank's vision and the changes brought by the pandemic and the phenomenon of digital transformation. It should be emphasized that these are not the goals set by the bank, which are a real part of its business. However, these are goals that the bank could set itself. In relation to the proposed goals, the following tables present the KPIs by means of which it is possible to measure the achievement of the potential goals.

Monitoring KPIs for financial goals can provide the bank with information on whether the products and services they offer at a given time are profitable, ensure the company's growth and provide shareholder value [86]. By examining selected KPIs (Table 6), the bank will also be able to understand the success and use of established digital technologies in its internal processes or the activities of growth of its employees.

Table 6. KPIs of financial perspective.

\begin{tabular}{ccc}
\hline Perspective & Goals & KPIs \\
\hline \multirow{2}{*}{$\begin{array}{c}\text { Financial } \\
\text { perspective }\end{array}$} & $\begin{array}{c}\text { Reduction in operating costs by } \\
\text { focusing on technological } \\
\text { advancements }\end{array}$ & $\begin{array}{c}\text { Structure of operating costs } \\
\text { Share of ICT costs in total costs } \\
\text { Return on investment in ICT }\end{array}$ \\
\cline { 2 - 3 } & $\begin{array}{c}\text { Increase revenue from the provision } \\
\text { of new digital products and services }\end{array}$ & $\begin{array}{c}\text { Share of revenues from digital } \\
\text { products and services in total } \\
\text { revenues }\end{array}$ \\
\hline
\end{tabular}

The COVID-19 pandemic accelerated digitization of some of UniCredit's internal processes. Therefore, it is appropriate to examine the costs that are associated with it. From the financial perspective, one of the bank's goals can be the reduction in operating costs 
by the use of digital technologies (Table 6). Costs that should be measured for this goal are costs associated with ICTs, their maintenance, energy consumption and labor costs for workers who directly use ICTs. The bank's financial goal in connection with the digital transformation may also be to increase revenue from the provision of new digital products and services. This means that the profitability of digital products that the bank invested in needs to be measured. These investments were either in new digital products or in the digital-optimization of its internal processes. For this purpose, the bank may monitor, for example, the share of revenues from digital products and services in total revenues.

The KPIs of the customers perspective can help a bank know which market requirements or new products and services have a certain advantage over the competition. In this way, the bank will be able to compare the performance of processes focused on the provision of banking products and services influenced by digital technologies (Table 7).

Table 7. KPIs of customers perspective.

\begin{tabular}{|c|c|c|}
\hline Perspective & Goals & KPIs \\
\hline \multirow{5}{*}{$\begin{array}{l}\text { Customers } \\
\text { perspective }\end{array}$} & $\begin{array}{l}\text { Improvement of the } \\
\text { customer service } \\
\text { availability }\end{array}$ & $\begin{array}{c}\text { Number of downloads of the Smart Banking } \\
\text { mobile application } \\
\text { Number of generated authentication tokens } \\
\text { Number of expired authentication tokens } \\
\text { Customer satisfaction with the Smart Banking } \\
\text { mobile application } \\
\text { API response time } \\
\text { Customer participation in digital channels }\end{array}$ \\
\hline & Attracting new customers & $\begin{array}{c}\text { Customer attract rate } \\
\text { Customer satisfaction with service levels } \\
\text { Customer satisfaction with new products and } \\
\text { services } \\
\text { New customer acquisition rate }\end{array}$ \\
\hline & Retain existing customers & Customer retention rate \\
\hline & $\begin{array}{l}\text { Improving the UniCredit } \\
\text { Bank's interaction with the } \\
\text { customer }\end{array}$ & Customer effort score (CES) \\
\hline & $\begin{array}{c}\text { Increase customer } \\
\text { engagement }\end{array}$ & Customer engagement ratio \\
\hline
\end{tabular}

Within a part of the customer perspective (Table 7), in response to the digitalization trend, the bank seeks to expand the channels through which it can connect with its customers. As we found out by examining the bank's business activities during the pandemic, UniCredit Bank has introduced a new channel that connects the bank with the customers, namely a mobile application: Smart Banking. The bank's goal is to strive to improve the availability of customer services. As part of this goal, the bank can monitor the number of downloads of the Smart Banking mobile application, the number of active users of this application, the number of generated or expired authentication tokens, customer satisfaction with the mobile application or API (application programming interface) response time.

In the area of customer satisfaction with the mobile application, the KANO model can be used as one of the quality management procedures. This model emphasizes the diversity of customer requirements according to their importance for their satisfaction. The KANO model is based on the existence of two key dimensions of quality, which are the degree of fulfilment of customer requirements and the degree of customer satisfaction [87]. It is also important for the bank to monitor customer participation in digital channels.

Adaptation to new technologies represents a certain competitive advantage for the bank and a greater chance of attracting a new customers. As a part of this goal, the bank can monitor, for example, the level of customer attraction. In regard to service quality, there are three KPIs that UniCredit Bank should focus on: \% customer satisfaction with 
service levels, \% customer satisfaction with new products and services and new customer acquisition rate.

It is also important for the bank to retain existing customers, so it can also monitor the customer retention rate as part of this goal (Table 8). Digitizing products and services, as well as expanding digital channels and providing services according to customer needs, is one way of retaining existing customers. This can also be considered important in the context of improving the bank's interaction with customers. Within this goal, the bank can monitor, for example, the customer effort score. One of the bank's goals may be to increase customer engagement; therefore, it can monitor the customer engagement rate to meet this strategic goal.

Table 8. KPIs of internal processes perspective.

\begin{tabular}{|c|c|c|}
\hline Perspective & Goals & KPIs \\
\hline \multirow{4}{*}{$\begin{array}{l}\text { Internal } \\
\text { processes } \\
\text { perspective }\end{array}$} & $\begin{array}{l}\text { Digitalization of internal } \\
\text { processes }\end{array}$ & $\begin{array}{c}\text { Increase in the number of mortgage } \\
\text { applications per year } \\
\text { Share of electronic transactions } \\
\text { Number of digitally approved credit cases } \\
\text { Share of digitally processed documents on } \\
\text { total processed documents } \\
\text { Shareholder expectations }\end{array}$ \\
\hline & $\begin{array}{l}\text { Improvement of the security } \\
\text { of processes and activities }\end{array}$ & $\begin{array}{c}\text { Number of online banking security breaches } \\
\text { Number of fraudulent transactions }\end{array}$ \\
\hline & $\begin{array}{l}\text { Streamlining the recruitment } \\
\text { process of digital workforce }\end{array}$ & $\begin{array}{l}\text { Number of responses to candidates via } \\
\text { chatbot per month } \\
\text { Number of applicants addressed via chatbot } \\
\text { per month }\end{array}$ \\
\hline & $\begin{array}{l}\text { Introduction of new digitized } \\
\text { product and services }\end{array}$ & $\begin{array}{l}\text { Number of new digitized products and } \\
\text { services introduced per year } \\
\text { New product launch time }\end{array}$ \\
\hline
\end{tabular}

From the perspective of internal processes (Table 8), the bank can set goals such as the digitization of internal processes, streamlining the recruitment process, or the introduction of new products and services. The UniCredit Bank can measure the fulfillment of the goals, focused on the digitization of internal processes, through KPIs such as: increase in the number of mortgage applications per year, the share of electronic transactions, number of digitally approved credit cases or share of digitally processed documents on total processed documents.

In connection with the growth of electronic banking, fraud and misuse of customer data can occur. It is also necessary for the bank to communicate and share knowledge in order to strengthen data security that helps avoid customers identify fraud [88]. Therefore, the bank's goal may be to improve security, especially in connection with making payments online or via a mobile application. The UniCredit Bank may monitor the fulfillment of this goal through KPIs, such as the number of breaches of online banking security or the number of fraudulent transactions.

The UniCredit Bank can measure the fulfillment of the goal aimed at streamlining the recruitment process through KPIs, such as the number of responses to candidates via a chatbot per month or the number of applicants addressed through a chatbot per month (Table 9). The goal focused on the introduction of new digitized products and services can be measured through KPIs, such as the number of new digitized products and services per year or new product launch time. 
Table 9. KPIs of learning and growth perspective.

\begin{tabular}{|c|c|c|}
\hline Perspective & Goals & KPIs \\
\hline \multirow{7}{*}{$\begin{array}{l}\text { Learning and } \\
\text { Growth } \\
\text { perspective }\end{array}$} & $\begin{array}{l}\text { Continuing education and } \\
\text { retraining of employees at } \\
\text { a distance }\end{array}$ & $\begin{array}{c}\text { Number of completed trainings per } \\
\text { employee per year } \\
\text { Expenditure on employee training per year }\end{array}$ \\
\hline & $\begin{array}{l}\text { Improving productivity of } \\
\text { employees }\end{array}$ & $\begin{array}{l}\text { Profit on employee } \\
\text { Labor productivity }\end{array}$ \\
\hline & ICT modernization & $\begin{array}{c}\text { Increase in investment in modern ICT } \\
\text { equipment }\end{array}$ \\
\hline & $\begin{array}{l}\text { Increase the digital literacy of } \\
\text { employees-digital workforce }\end{array}$ & $\begin{array}{l}\text { Level of digital skills of employees } \\
\text { Complementarity between digital and } \\
\text { non-digital skills in the workplace }\end{array}$ \\
\hline & Reduction in employee turnover & Fluctuation rate \\
\hline & $\begin{array}{l}\text { Creating a digital and flexible } \\
\text { workplace culture }\end{array}$ & $\begin{array}{l}\text { Employee satisfaction with ICT used at } \\
\text { work } \\
\text { Employee satisfaction with working hours } \\
\text { and working arrangements } \\
\text { Use of modern communication tools (Slack, } \\
\text { MS Teams, Workplace by Facebook. . ) } \\
\text { Use of flexible forms of employment (job } \\
\text { sharing, platform work, ICT-based mobile } \\
\text { work... ) } \\
\text { Degree of self-control and ability of } \\
\text { employees to organize themselves }\end{array}$ \\
\hline & $\begin{array}{l}\text { Digital human resources } \\
\text { management }\end{array}$ & $\begin{array}{l}\text { Use of digital tools and application (HR } \\
\text { analytics, e-recruitment, e-learning, } \\
\text { bots... ) } \\
\text { Satisfaction with the quality of digital tools } \\
\text { and applications used in human resource } \\
\text { management }\end{array}$ \\
\hline
\end{tabular}

In terms of the learning and growth perspective (Table 9), UniCredit Bank may set goals for distance training of employees during a pandemic, where it can monitor KPIs as the number of distance training per employee per year or the expenditure on such training per employee per year. Within this perspective, a goal can also be aimed at improving employee productivity, where UniCredit Bank can monitor, for example, profit per employee or direct labor productivity.

Another goal may be focused on the modernization of ICTs, the fulfillment of which the bank can monitor through expenditures on investments in the modernization of its ICT equipment. Employees are important for every organization, and it is necessary to monitor their satisfaction and motivation. For example, benefits are a great opportunity to lure, raise and keep employees. Only satisfied employees can identify with the company and do their best work [89]. One of UniCredit's goals may also be to ensure employee satisfaction, which the bank will monitor through regular employee satisfaction surveys.

The digital literacy of employees is also closely related to the digitization of processes, so it should be important for the bank to focus on increasing the digital literacy of its employees. The fulfillment of this strategic goal can be monitored by the bank through indicators such as the level of digital skills of employees (no ICT skills to advanced level of ICT skills). It can also monitor the complementarity between digital and non-digital skills and the like. The digital transformation can also have an impact on employee turnover-especially on employees with no to low levels of digital skills. Therefore, it is necessary to monitor the fluctuation rate. As part of the digital transformation, organizations are also working to create a culture of digital and flexible workplaces, so the bank should monitor employee satisfaction with the ICT tools the bank uses, employee satisfaction with working hours 
and work schedule as well as the degree of use of modern communication tools, such as Slack, Workplace, Microsoft Teams and the like. It should also monitor the share of flexible forms of employment, such as employee sharing, job sharing, voucher-based work, casual work, ICT-based mobile work, platform work, portfolio work or collaborative work.

Within these flexible forms of employment, it is important for employees to monitor the degree of self-control and the ability to self-organize. The digital transformation affects almost every area of business. Human resource management is no exception, and organizations are working to digitize human resource management processes. Therefore, it is important to monitor, in particular, the use of digital tools and applications and satisfaction with the quality of these tools and applications that HR professionals use in the bank.

Summarizing all the findings: by linking Tables 4-8 and assigning the proposed KPIs of the BSC perspectives to the individual parts of the BMC, we created an overview of the KPIs (Table 10). Those KPIs that contribute to the long-term sustainability of UniCredit Bank are highlighted in green. By monitoring these indicators, the sustainability of the selected bank increases. If the value of these indicators increases, then the selected bank operates without paper, and thus the environment is protected.

Table 10. Overview of proposed KPIs.

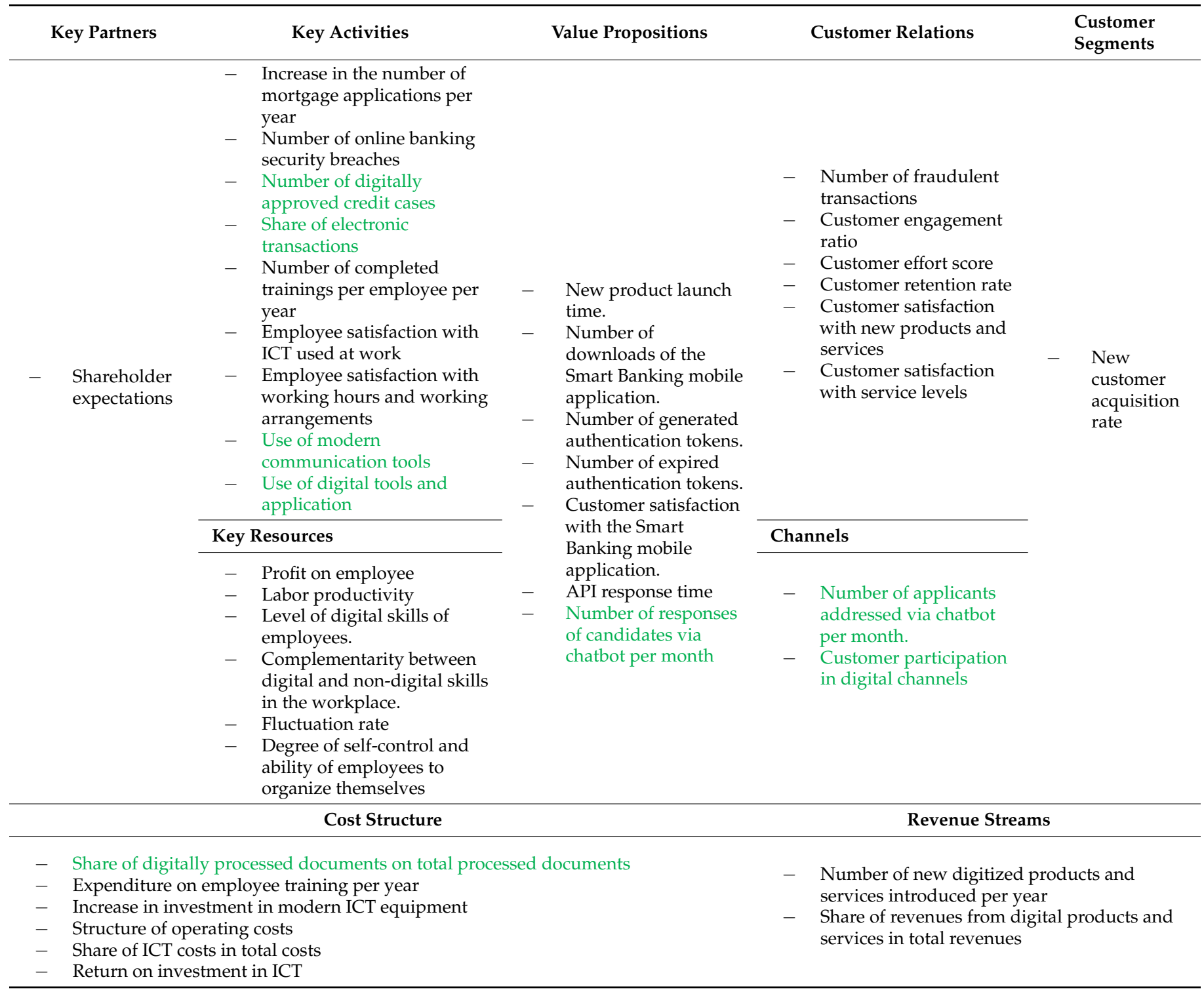




\section{Discussion}

The scientific contribution of the article and this case study lies in the integration of the BSC to the BMC (Table 5). The integration of both tools helped us to identify changes in the bank's business models caused by the COVID-19 pandemic, which was the driving force behind the continuing trend of the digital transformation of the business sector. By connecting both the BMC and BSC tools, we created a framework for measuring the performance of the company's business models grouped into nine BMC building blocks (Table 10).

Our proposed model of connecting the BSC with BMC is not perfect. In this way, we want to stimulate a debate on how other strategic management tools could be integrated to better capture the changes generated by digital transformation.

A similar study aimed at linking two theoretical frameworks, the Business Model Canvas and the Global Alliance for Banking on Values' six principles, was conducted. The research was carried out in Hungary, and the aim of the research was to examine the approaches of a selected Hungarian bank to the realization of banking activities. Subsequently, researchers compared how the bank's operations differ from the traditional ones. The authors found that individual principles can be integrated into individual areas of the Business Model Canvas. For example, the client-oriented principle may be included in the area of customer relationships, or the principle of transparency may be included in revenue streams and the like [90].

If links between different methods of strategic management exist, what other methods and approaches should be linked together for better understanding the changes affecting the ways businesses operate?

Despite the fact that the examined bank did not change all of its business models, or at least part of each business model, it can be expected that, in the future, digitization will affect all of its business models. Therefore, in our research, we designed a set of multiple KPIs for all BSC perspectives. For all the KPIs, we modeled possible goals that the bank would want to achieve. By monitoring the proposed KPIs, the bank will be able to evaluate the success of activities that have been digitized. In addition, to examine how a business has digitalized, KPIs can also provide information if the bank contributes to the long-term sustainability.

The research has one limitation. The proposed KPIs were not mathematically quantified. Underlying data that would enter into such calculations were not publicly available, and the bank did not want to provide them for us. We can conclude that this is the limitation of our research, and the real quantification of the proposed KPIs represents suggestions for further research.

In general, we can conclude that the COVID-19 pandemic forced many businesses and industries to adapt and innovate existing business models and practices. The banking sector is a suitable example of this. Although banking has shifted towards the digitalization of its processes over the last decade, the ongoing COVID-19 pandemic has accelerated this trend even further as people avoid personal interactions, fewer people visit physical banks and more people move into online space. More and more people are also preferring contactless payment methods and moving more transactions to peer-to-peer payments [91].

The changes in the business models we analyzed relate to digital transformation; thus, another topic of discussion is the further direction of the banking sector.

It can be stated that the term digital banking has taken on a new meaning. Until 2020, i.e., before and at the beginning of the pandemic, digital banking was limited only to web and mobile applications [91]. At the same time, banks must respond to FinTech and BigTech companies, which are entering the banking industry faster than ever before. Companies such as Google, Facebook, Apple or Amazon offer banking and financial services products directly to the consumer. BigTech companies leverage their extensive user base, build on existing infrastructure and offering customers a wide range of digital products and services. This poses a serious threat to traditional banks [92,93]. The COVID-19 pandemic and technology giants have given digital banking a new direction. The digital banking 
sector could experience huge developments in the near future. Technology trends related to blockchain, the Internet of Things, and artificial intelligence will eventually dominate banking technologies [92].

Some proponents of blockchain technology believe that it can be used to create safer and more convenient alternatives to time-consuming and costly banking processes. Currently, this technology is being tested and analyzed by some large banks in an effort to reduce the number of participants involved in financial transactions. Most of these banks' research is currently focused on explaining technical details and examining the theoretical use of this technology. Few banks have created their own systems based on blockchain technology without the help of external partners-technology solution providers [94]. For some types of payments, blockchain technology (or distributed ledger technology) enables more cost-effective, secure and fully traceable cash flow. In the area of cross-border payments, the blockchain enables almost instantaneous and transparent payments, and thus this technology eliminates complex fee structures $[95,96]$. It can be stated that interest in blockchain is still growing exponentially, especially in the financial services industry. Unlike traditional transactions, which depend heavily on central counterparties for clearing and storing information, blockchain transactions are managed by a network of nodes, which results in faster clearing times, fewer redundant intermediaries, and, ultimately, lower costs [97].

The Internet of Things (IoT) is currently emerging as the next trend in technology, with repercussions across the spectrum of society and business, and [98] it also has the potential to influence the traditional business processes in banking. The IoT, in conjunction with other new technologies, can create new business models [99]. Banks with the IoT can link all their devices and allow them to control their accounts from any of these devices (or a central device). As with other groundbreaking technologies, user acceptance is important. In this case, a better organizational understanding and discussion of the technology, its benefits and problems would be needed. Success in bringing organizations into smart ecology depends to a large extent on people's attitudes and motivation towards the IoT. They must voluntarily allow IT ideology to penetrate the core of their institutional domains and exist at the core of their daily lives, influencing the way they act and think [100].

Some companies experiment, for example, with biometric payments. An example is Amazon, which created a chain of Amazon GO stores that are partially automated. This contactless identification service links customer credit cards with palm prints and creates a unique biometric signature. Customers pay in the store just by holding their palm over the Amazon One device that connects customers' Amazon account with the payment card [95].

In connection with the IoT, there is another trend for future banking-artificial intelligence. Banks have extensive data on their customers that can be used to predict their future requirements. In this case, artificial intelligence can help banks to use this knowledge by adapting tenders for customers [92]. Artificial intelligence can also be used to monitor new generations of banking fraud. An example can be VISA, which used models of artificial intelligence and machine learning to explore more than 500 real-time transaction attributes and thus, by exploring these transactions, prevented a billion-dollar fraud [95].

Human resources (HR) are also very important for the efficient functioning of banks. Digitalization and automation in this area represents a solution for efficient and functional human resources management, which is accurate, fast and able to continuously process large amounts of data. When a company can organize, operate and behave in a digital way, it can create a workplace that does not only equip teams but also empowers them [101]. HR management is increasingly beginning to use machine learning technology, which falls under the field of artificial intelligence. HR uses machine learning to plan HR functions. It is also used in the analysis and processing of relevant information, streamlining work procedures, improving recruitment procedures [102,103], reducing staff turnover [104,105] and training [106]. It can also be used in measuring and managing employee involvement and improving reward programs (incentive programs) [107]. Artificial intelligence becomes a key engine in the individual phases of an employee's life cycle. With the right combination 
of personal communication and digital means, it is possible to improve the quality of the tasks performed and minimize the workload of HR departments [108].

The future of human resources is, therefore, both digital and human. HR managers should focus on optimizing the combination of both human and automated work. The future of HR is the necessity of knowing how to use and how to acquire new knowledge. Knowledge management, as a means of gaining or maintaining a competitive advantage for the bank, is a key element or tool in helping organizations to better adapt to digital transformation's future trends [109-111].

If banks focus on the use of new, more modern digital technologies, the digital transformation of banks will deepen. If the digital transformation of banks leads to paperless banking, then the long-term sustainability of banking can be guaranteed to some extent by the digitalization of banking processes.

\section{Conclusions}

Technological innovation and digital transformation are challenges and opportunities that represent the future of the banking sector. Digital transformation is a process in which organizations must respond flexibly to changes in technological progress and the requirements of their customers in order to be competitive. It is also important to increase the efficiency of processes by using digital technologies, from which not only banks but also their customers can benefit.

Digital technologies penetrate every sector, and they have a significant presence in the banking sector. Traditional banking systems are now obsolete, and, in order to be competitive, banks must reflect the needs of their customers, especially Generation Z, who see technology as an integral part of their everyday life [93,112]. Today, digital banking is no longer just an option but a necessity that banks must accept and optimize and adapt to their strategic goals.

The aim of this case study was to analyze the changes in the business models of the selected organization, in this case, UniCredit Bank. The analyzed changes were caused by the digital transformation that was triggered by the COVID-19 pandemic. We used a suitable tool for such a comparison-the BMC. The BMC provides an overview not only of the key resources and activities but also for business value propositions, customer relations, channels and customer segments, cost structure and sources of revenue.

The findings we gathered in compiling the information for the BMC point to the changes in certain aspects of UniCredit's business models, which were digitally transformed. Based on these findings, it can be stated that digital transformation plays an important role, which corresponds to the growing demand for the simplification and optimization of UniCredit's processes. The digital transformation had a significant representation, especially in the area of value proposition, where it had an impact on the digitization of current and introduction of entirely new banking products and services. It has also significantly affected the internal processes and activities in the field of HR management. The bank started to use chatbots in communication with potential job seekers. Due to the pandemic and the protection of the health and safety of employees, UniCredit Bank was forced to introduce work from home for employees, to whom it also provided suitable work aids and distance training. The changes due to the pandemic also affected the area of channels, where the mobile application Smart Banking was introduced. The application makes it easier for customers to access their banking accounts. Security is also closely linked to digitization and digital transformation, and the bank introduced double authentication (also in the context of the new PSD2) for its online payments.

In order to measure the success of the changes, we proposed a set of KPIs grouped under the framework of BSC, which we interlinked with the framework of BMC. BSC, in the case of this case study, took into account the bank's potential goals. These goals were formulated with regard to the changes resulting from our analysis. Based on our proposals, it is possible to expand the BSC perspectives with new sub-perspectives in which the proposed KPIs provide UniCredit Bank with information on which indicators it 
can use to measure the success of the digital transformation of its business models. The proposed set of KPIs also provides information on which of these indicators, by increasing their values, can contribute to the long-term sustainability of banking. If the values of these indicators increase, paperless banking emerges. If a reduction in the use of paper helps protect forests and the environment, digitally enhanced banking thus represents an opportunity to provide more sustainable banking services.

Author Contributions: Conceptualization, R.C. and K.S.; methodology, R.C.; validation, M.S.; formal analysis, K.S. and M.S.; data curation, R.C. and K.S.; writing-original draft preparation, K.S. and R.C.; writing-review and editing, K.S., R.C. and M.S.; supervision, M.S.; funding acquisition, M.S. All authors have read and agreed to the published version of the manuscript.

Funding: This article was funded by the scientific grant agency of The Ministry of Education, Science, Research and Sport of the Slovak Republic and Slovak Academy of Sciences, which provided financial resources for the research project VEGA 1/0011/21 No. 16989-Research on the interactions among new emerging technologies, the performance of enterprises and industries based on network technology infrastructure, the application of new business models and the institutional regulatory, environmental and social environment.

Institutional Review Board Statement: Not applicable.

Informed Consent Statement: Not applicable.

Acknowledgments: This research was supported by project VEGA 1/0011/21 Research on the interactions among new emerging technologies, the performance of enterprises and industries based on network technology infrastructure, the application of new business models and the institutional regulatory, environmental and social environment.

Conflicts of Interest: The authors declare no conflict of interest.

\section{References}

1. Kaushik, M.; Guleria, N. The Impact of Pandemic COVID-19 in Workplace. Eur. J. Bus. Manag. 2020, 12, 9-18. [CrossRef]

2. Bennett, R.A. Year Into the COVID-19 Pandemic: What Have We Learned About Workplaces and What Does the Future Hold? The National Law Review, 16 March 2021; 75.

3. Dwivedi, Y.K.; Hughes, D.L.; Coombs, C.; Constantiou, I.; Duan, Y.; Edwards, J.S.; Gupta, B.; Lal, B.; Misra, S.; Prashant, P.; et al. Impact of COVID-19 pandemic on information management research and practice: Transforming education, work and life. Int. J. Inf. Manag. 2020, 55, 102211. [CrossRef]

4. Singh, A. Work Life Balance During Covid Pandemic. TURCOMAT 2021, 12, 516-520. [CrossRef]

5. Ancillo, A.; del Val Núñez, M.; Gavrila, S. Workplace change within the COVID-19 context: A grounded theory approach. Econ. Res. Ekon. Istraž. 2020, 34, 2297-2316. [CrossRef]

6. Nilles, J.M. Traffic reduction by telecommuting: A status review and selected bibliography. Econ. Res. Ekon. Istraž. 1988, 34, 2297-2316. [CrossRef]

7. Messenger, J.C.; Gschwind, L. Three generations of Telework: New ICTs and the (R)evolution from Home Office to Virtual Office. New Technol. Work Employ. 2016, 31, 195-208. [CrossRef]

8. Remote Work-Gartner Glossary. Available online: https://www.gartner.com/en/information-technology/glossary/remotework (accessed on 14 September 2021).

9. Neeley, T. Remote Work Revolution, 1st ed.; HarperCollins Publishers: New York, NY, USA, 2021; pp. 40-58.

10. Eurofound. Working Anytime, Anywhere: The Effects on the World of Work. Available online: https:/ / www.eurofound.europa. eu/sites/default/files/ef_publication/field_ef_document/ef1658en.pdf (accessed on 5 August 2021).

11. Eurostat. Employed Persons Working from Home as a Percentage of the Total Employment, by Sex, Age and Professional Status (\%). Available online: https:/ / ec.europa.eu/eurostat/databrowser/view/lfsa_ehomp/default/table?lang=en (accessed on 5 August 2021).

12. Statista. Remote Work Prior to COVID-19 Worldwide 2020 I Statista. Available online: https:/ / www.statista.com/statistics / 1220 141/remote-work-prior-covid-worldwide/ (accessed on 5 August 2021).

13. European Commission. Telework in the EU Before and After the COVID-19: Where We Were, Where We Head To. Available online: https:/ / ec.europa.eu/jrc/sites/default/files/jrc120945_policy_brief_-_covid_and_telework_final.pdf (accessed on 5 August 2021).

14. Frequency of Remote Working in Poland in 2021. Available online: https://www.statista.com/statistics/1232607/polandfrequency-of-remote-working/ (accessed on 14 September 2021).

15. Savić, D. COVID-19 and Work from Home: Digital Transformation of the Workforce. Grey J. 2020, 16, 101-104. 
16. Genzorova, T.; Corejova, T.; Stalmasekova, N. How digital transformation can influence business model, Case study for transport industry. Transp. Res. Procedia 2019, 40, 1053-1058. [CrossRef]

17. Batocchio, A.; Minatogawa, V.; Anholon, R. Proposal for a Method for Business Model Performance Assessment: Toward an Experimentation Tool for Business Model Innovation. J. Technol. Manag. Innov. 2017, 12, 61-70. [CrossRef]

18. Salgado, C.; Maciel, R. Exploring a Three-Dimensional, Requirements-Based, Balanced Scorecard Business Model. In Proceedings of the IEEE 17th Conference on Business Informatics, Lisbon, Portugal, 13-16 July 2015. [CrossRef]

19. Owens, T.; Padilla, T. Digital sources and digital archives: Historical evidence in the digital age. Int. J. Digit. Humanit. 2020, 1 , 325-341. [CrossRef]

20. Gartner. Definition of Digitization-Glossary | Gartner. Available online: https://www.gartner.com/en/informationtechnology/glossary/digitization (accessed on 6 August 2021).

21. Madlenak, R.; Madlenakova, L.; Svadlenka, L. Analysis of Website Traffic Dependence on Use of Selected Internet Marketing Tools. Procedia Econ. Financ. 2015, 23, 123-128. [CrossRef]

22. Madlenak, R.; Madlenakova, L.; Rudawska, A. Viral Marketing as Part of Effective University Marketing Strategy. In INTED2017 Proceedings, Proceedings of the 11th International Technology, Education and Development Conference, Valencia, Spain, 6-8 March 2017, 1st ed.; Chova, L.G., Martinez, A.L., Torres, I.C., Eds.; IATED Academy: Madrid, Spain, 2017; Volume 9, pp. 5629-5634. [CrossRef]

23. SAP Insights. Digitization vs Digitalization I SAP Insights. Available online: https://insights.sap.com/digitization-vsdigitalization/ (accessed on 6 August 2021).

24. Gartner. Definition of Digitalization-IT Glossary | Gartner. Available online: https://www.gartner.com/en/informationtechnology/glossary/digitalization (accessed on 6 August 2021).

25. Madudova, E.; Corejova, T.; Valica, M. Economic Sustainability in a Wider Context: Case Study of Considerable ICT Sector Sub-Divisions. Sustainability 2018, 10, 2511. [CrossRef]

26. Corejova, T.; Madudova, E. Trends of scale-up effects of ICT sector. Transp. Res. Procedia 2019, 40, 1002-1009. [CrossRef]

27. Savić, D. From Digitization, through Digitalization, to Digital Transformation. Online Search. 2019, 43, 36-39.

28. Madlenak, R.; Madlenakova, L.; Kolarovszka, Z. System of management and traceability of logistic items through new technologies. Procedia Soc. Behav. Sci. 2016, 230, 128-135. [CrossRef]

29. Statista. Digital Transformation-Statistics \& Facts. Available online: https://www.statista.com/topics/6778/digitaltransformation/\#dossierSummary_chapter2 (accessed on 6 August 2021).

30. What Are Socio-Technical Systems? Available online: https://www.interaction-design.org/literature/topics/socio-technicalsystems (accessed on 9 December 2021).

31. Stalmasekova, N.; Genzorova, T.; Corejova, T.; Gasperova, L. The impact of using the digital environment in transport. Procedia Eng. 2017, 192, 231-236. [CrossRef]

32. Verhoef, P.C.; Broekhuizen, T.; Bart, Y.; Bhattacharya, A.; Qi Dong, J.; Fabian, N.; Haenlein, M. Digital transformation: A multidisciplinary reflection and research agenda. J. Bus. Res. 2021, 122, 889-901. [CrossRef]

33. Chinoracky, R.; Corejova, T. Impact of Digital Technologies on Labor Market and the Transport Sector. Transp. Res. Procedia 2019, 40, 994-1001. [CrossRef]

34. van Deursen, A.; van Dijk, J. Internet skills and the digital divide. News Media Soc. 2011, 12, 893-911. [CrossRef]

35. Inštitút pre Verejné Otázky. Digitálna Gramotnost' na Slovensku. 2020. Available online: https://www.ivo.sk/buxus/docs/ /publikacie/subory/Digitalna_gramotnost_2020.pdf (accessed on 7 August 2021).

36. Nambisan, S.; Wright, M.; Feldman, M. The digital transformation of innovation and entrepreneurship: Progress, challenges and key themes. Res. Policy 2019, 48, 103773. [CrossRef]

37. Vial, G. Understanding digital transformation: A review and a research agenda. J. Strateg. Inf. Syst. 2019, 28, 118-144. [CrossRef]

38. Kremenova, I.; Gajdos, M. Decentralized Networks: The Future Internet. Mob. Netw. Appl. 2019, 24, 2016-2023. [CrossRef]

39. Kvasnicova, T.; Kremenova, I.; Fabus, J. From an analysis of e-services definitions and classifications to the proposal of new e-service classification. Procedia Econ. Financ. 2016, 39, 192-196. [CrossRef]

40. Madlenak, R.; Madlenakova, L. The Differences in Online Advertising Acceptance in China and Slovakia. AEBMR Adv. Econ. Bus. Manag. Res. 2015, 3, 45-49. [CrossRef]

41. Socio-Technical Systems: Change Management in a Pandemic. Available online: https://www.newswise.com/articles/sociotechnical-systems-change-management-in-a-pandemic (accessed on 9 December 2021).

42. Narayanamurthy, G.; Tortorella, G. Impact of COVID-19 outbreak on employee performance-Moderating role of industry 4.0 base technologies. Int. J. Prod. Econ. 2021, 234, 108075. [CrossRef]

43. Gupta, A. Accelerating Remote Work after COVID-19. Available online: https://www.thecgo.org/research/accelerating-remotework-after-covid-19/ (accessed on 7 August 2021).

44. Almeida, F.; Duarte Santos, J.; Augusto Monteiro, J. The Challenges and Opportunities in the Digitalization of Companies in a Post-COVID-19 World. IEEE Eng. Manag. Rev. 2020, 48, 97-103. [CrossRef]

45. Microsoft. A Guide to the Future How Companies Across Industries in Central and Eastern Europe Approach the Digital Revolution. Available online: https://news.microsoft.com/uploads/prod/sites/52/2018/11/CEE_DT_thought_leadership_ebook.pdf (accessed on 7 August 2021).

46. Dugelova, M.; Strenitzerova, M. The Using of Data Envelopment Analysis in Human Resource Controlling. Procedia Econ. Financ. 2015, 26, 468-475. [CrossRef] 
47. Microsoft News Center. Technológie Menia Bankový Biznis a Kultúru Práce vo Financiách I Microsoft News Center. Available online: https: / / news.microsoft.com/sk-sk/2019/03/06/technologie-menia-bankovy-biznis-a-kulturu-prace-vo-financiach/ (accessed on 8 August 2021).

48. Deloitte. COVID-19 a Jeho Vplyv na Finančný Sector. Available online: https://www2.deloitte.com/sk/sk/pages/aboutdeloitte/articles/covid-19-financny-sektor.html (accessed on 8 August 2021).

49. Riva, A.; Pilotti, L. Digital and lean transformation in the bank and in the financial services: The experience of Unicredit Bank. Int. J. Manag. Res. Bus. Strategy 2018, 2, 1-23.

50. UniCredit Bank. Kto Sme. Available online: https://www.unicreditbank.sk/sk/private-banking/o-nas/kto-sme.html (accessed on 9 August 2021).

51. Chief-Digital-Officers.com. How UniCredit CDO Deals with Digitalization. Available online: https://chief-digital-officers.com/ en/how-unicredit-cdo-deals-with-digitalization/ (accessed on 9 August 2021).

52. Harvard Business Review. A Better Way to Think About Your Business Model. Available online: https://hbr.org/2013/05/abetter-way-to-think-about-yo (accessed on 8 August 2021).

53. Harvard Business Review. What Is a Business Model? Available online: https://hbr.org/2015/01/what-is-a-business-model) (accessed on 8 August 2021).

54. SBA. Mapa k Vášmu Úspechu na Jednej Strane. Vytvorte si Business Model Canvas. Available online: http://www.sbagency.sk/ mapa-k-vasmu-uspechu-na-jednej-strane-vytvorte-si-business-model-canvas\#.YQzWIYgzaUl (accessed on 8 August 2021).

55. Osterwalder, A.; Pigneur, Y. Business Model Generation: A Handbook for Visionaries, Game Changers, and Challengers; John Wiley \& Sons: Hoboken, NJ, USA, 2010.

56. Soderberg, M.; Kalagnanam, S.; Sheehan, N.T.; Vaidyanathan, G. When is a balanced scorecard a balanced scorecard? Int. J. Product. Perform. Manag. 2011, 60, 688-708. [CrossRef]

57. Chytas, P.; Glykas, M.; Valiris, G. A proactive balanced scorecard. Int. J. Inf. Manag. 2011, 31, 460-468. [CrossRef]

58. Chavan, M. The balanced scorecard: A new challenge. J. Manag. Dev. 2009, 28, 393-406. [CrossRef]

59. Chan, T.K.; Hiap, P.T. A Balanced Scorecard Approach to Measuring Industry Performance. J. Constr. Dev. Ctries. 2012, 17 (Suppl. S1), 23-41.

60. Kaplan, R.S.; Norton, D.P. Balanced Scorecard: Translating Strategy into Action, 1st ed.; Harvard Business School Press: Boston, MA, USA, 1996; pp. 47-146.

61. Balanced Scorecard. Available online: https://www.calltheone.com/en/consultants/balanced-scorecard (accessed on 14 August 2021).

62. Harvard Business Review. The Balanced Scorecard-Measures that Drive Performance. Available online: https://hbr.org/1992/0 1/the-balanced-scorecard-measures-that-drive-performance-2 (accessed on 9 August 2021).

63. Balanced Scorecard Institute. Balanced Scorecard Basics. Available online: https://balancedscorecard.org/bsc-basics-overview/ (accessed on 9 August 2021).

64. UniCredit Bank. Výročná Správa UniCredit Banky. 2019. Available online: https://www.unicreditbank.sk/content/dam/cee202 0-pws-sk/sk-dokumenty/o_banke/vysledky/vyrocneSpravy/VZ_2019_SK.pdf (accessed on 10 August 2021).

65. UniCredit. Shareholders. Available online: https://www.unicreditgroup.eu/en/governance/shareholders.html?topmenu=INTTM_GOV12_en034 (accessed on 11 August 2021).

66. European Central Bank. About European Central Bank. Available online: https://www.ecb.europa.eu/ecb/html/index.en.html (accessed on 10 August 2021).

67. Národná Banka Slovenska. Dohl’ad nad Finančným Trhom. Available online: https://www.nbs.sk/sk/dohlad-nad-financnymtrhom (accessed on 10 August 2021).

68. Epi.sk. Zákon č. 747/2004 Z. z. o Dohl'ade nad Finančným Trhom a o Zmene a Doplnení Niektorých Zákonov. Available online: https: / / www.epi.sk/zz/2004-747 (accessed on 10 August 2021).

69. Epi.sk. Zákon č. 483/2001 Z. z. o Bankách a o Zmene a Doplnení Niektorých Zákonov. Available online: https:/ / www.epi.sk/ zz/2001-483 (accessed on 10 August 2021).

70. UniCredit Bank. Riadená Otvorená Architektúra. Available online: https://www.unicreditbank.sk/sk/private-banking/ investicie/riadena-otvorena-architektura.html\#nasipartneri (accessed on 10 August 2021).

71. UniCredit Bank. Medzinarodná Spolupráca. Available online: https://www.unicreditbank.sk/sk/private-banking/o-nas/ medzinarodna-spolupraca.html\#privatebankingveurope (accessed on 10 August 2021).

72. UniCredit Bank. Zverejnenie Informácií Podl'a Opatrenia NBS č. 16/2014 o Uverejňovaní Informácií Bankami a Pobočkami Zahraničných Bank. Available online: https://www.unicreditbank.sk/content/dam/cee2020-pws-sk/sk-dokumenty/o_banke/ vysledky/povinne_udaje/UCBSK_NBS_povinne_zverejnenie_2020.pdf (accessed on 10 August 2021).

73. UniCredit. Brand Strategy. Available online: https://www.unicreditgroup.eu/en/unicredit-at-a-glance/our-identity/brandstrategy.html (accessed on 10 August 2021).

74. UniCredit. Brand and Communication. Available online: https://www.unicreditbank.si/en/about-us/UniCredit-Bank/Brandand-Communication.html (accessed on 10 August 2021).

75. Európska Centrálna Banka. Bankový Dohl’ad. Prečo Musia Banky Držat' Kapitál? Available online: https://www. bankingsupervision.europa.eu/about/ssmexplained/html/hold_capital.sk.html (accessed on 11 August 2021). 
76. UniCredit Bank. 3D Secure. Available online: https://www.unicreditbank.sk/en/other/3d-secure.html (accessed on 11 August 2021).

77. UniCredit Bank. Ochrana Súkromia. Available online: https://www.unicreditbank.sk/sk/ostatne/ochrana-sukromia.html (accessed on 11 August 2021).

78. UniCredit Bank. Občania. Available online: https://www.unicreditbank.sk/sk/obcania.html\#home (accessed on 11 August 2021).

79. Youtube. YouTube Channel of UniCredit Bank Slovensko. Available online: https://www.youtube.com/user/UniCreditBankSVK (accessed on 11 August 2021).

80. Twitter. Twitter Account UniCredit_CZSK. Available online: https://twitter.com/UniCredit_CZSK (accessed on 11 August 2021).

81. Národná Banka Slovenska. Zákon č. 747/2004 Z. z. o Dohl’ade nad Finančným Trhom. Available online: http://www.nbs.sk/ _img/Documents/_Legislativa/_UplneZneniaZakonov/Z7472004.pdf (accessed on 11 August 2021).

82. UniCredit Bank. Cenník Bankových Služieb pre Podnikatel'ov. Available online: https://www.unicreditbank.sk/content/ dam/cee2020-pws-sk/sk-dokumenty/ostatne/cenniky/15856_UCB_CENNIK_PODNIKATELIA_022019_SK.pdf (accessed on 11 August 2021).

83. UniCredit Bank. Finančné Poradenstvo ČR a SR. Available online: https://www.unicreditbank.sk/sk/velke-firmy/investicnebankovnictvo/ma-poradenstvo.html (accessed on 11 August 2021).

84. UniCredit Bank. Predstavenie SME Easy. Available online: https://www.unicreditbank.sk/sk/velke-firmy/sme-easy/ predstavenie-sme-easy.html (accessed on 11 August 2021).

85. UniCredit Bank. Výročná Správa UniCredit Banky. 2020. Available online: https://www.unicreditbank.sk/content/dam/cee202 0-pws-sk/sk-dokumenty/o_banke/vysledky/vyrocneSpravy/VS_UCB_2020_SK.pdf (accessed on 11 August 2021).

86. Performance Magazine. Insights on Developing a Bank's Balanced Scorecard. Available online: https://www.performancemagazine.org/banks-balanced-scorecard/ (accessed on 12 August 2021).

87. Rostasova, M.; Padourova, A.; Corejova, T. Kano model as a tool of effective customer satisfaction diagnostics of postal services. Entrep. Sustain. Issues 2020, 8, 811-828. [CrossRef]

88. Barker, R. Knowledge management to prevent fraudulent e-banking transactions. Communitas 2018, 23, 71-86. [CrossRef]

89. Stalmasekova, N.; Genzorova, T.; Corejova, T. Employee benefits as one of factors of work motivation. CBU Int. Conf. Proc. Innov. Sci. Educ. 2017, 5, 448-452. [CrossRef]

90. Győri, Z.; Khan, Y.; Szegedi, K. Business Model and Principles of a Values-Based Bank-Case Study of MagNet Hungarian Community Bank. Sustainability 2021, 13, 9239. [CrossRef]

91. Forbes. Pandemic Accelerated Digital Banking Tools in 2020 That Will Continue Far Beyond. Available online: https://www. forbes.com/sites/lizfrazierpeck/2021/01/15/pandemic-accelerated-digital-banking-tools-in-2020-that-will-continue-farbeyond/?sh=845992916239 (accessed on 12 August 2021).

92. Finextra. Trends That Will Shape Digital Banking's Future. Available online: https://www.finextra.com/blogposting/20494/ trends-that-will-shape-digital-bankings-future (accessed on 12 August 2021).

93. PWC. The Future of Digital Banking Explored. Available online: https://www.pwc.com/m1/en/media-centre/articles/thefuture-of-digital-banking-explored.html (accessed on 12 August 2021).

94. Financnytrh.com. Ako Banky a Finančné Inštitúcie Využívajú Technológiu Blockchain? Available online: https://www. financnytrh.com/banky-financne-institucie-vyuzivaju-technologiu-blockchain/ (accessed on 12 August 2021).

95. McKinsey \& Company. Technology-Led Shifts and Opportunities in Card-Based Payments. Available online: https://www. mckinsey.com/industries / financial-services/our-insights/banking-matters/technology-led-shifts-and-opportunities-in-cardbased-payments (accessed on 12 August 2021).

96. Sunyaev, A. Distributed Ledger Technology as a Game Changer. In Internet Computing; Springer: Cham, Switzerland, 2020; pp. 266-271.

97. Deloitte. Blockchain @ Rethinking Banking: A View on How Blockchain Can Change Banking. Available online: https://www2 .deloitte.com/content/dam/Deloitte/de/Documents/Innovation/Blockchain-Banking-Whitepaper-Deloitte-2017.pdf (accessed on 12 August 2021).

98. Park, Y. Understanding the internet of things ecosystem: Multi-level analysis of users, society, and ecology. Digit. Policy Regul. Gov. 2017, 19, 77-100.

99. Infosys Financle. IoT in Banking-Enabling Banks' Digital Future. Available online: https://www.edgeverve.com/finacle/ finacleconnect/trulydigital-2017/perspective/iot-banking-enabling-banks-digital-future/ (accessed on 12 August 2021).

100. Hwang, Y. Integrated acceptance and sustainability evaluation of internet of medical things: A dual-level analysis. Internet Res. 2018, 27, 1227-1254. [CrossRef]

101. Deloitte. Future of Work in Financial Services. Available online: https://www2.deloitte.com/us/en/pages/consulting/articles/ us-financial-workplace-of-the-future.html (accessed on 13 August 2021).

102. HR Technologist. What Is the Potential of Chatbots in Recruitment? Available online: https://www.hrtechnologist.com/articles/ digital-transformation/what-is-the-potential-of-chatbots-in-recruiting/ (accessed on 13 August 2021).

103. Send Pulse Blog. Chatbots Reduce Time to Hire and All the Related Costs. Available online: https://sendpulse.com/blog/ recruitment-chatbots\#Chatbots_reduce_time_to_hire_and_all_the_related_costs (accessed on 13 August 2021). 
104. Zhao, Y.; Hryniewicki, M.K.; Cheng, F.; Fu, B.; Zhu, X. Employee Turnover Prediction with Machine Learning: A Reliable Approach. In Advances in Intelligent Systems and Computing, Proceedings of the Conference on Intelligent Systems and Applications, IntelliSys, London, UK, 6-7 September 2018; Arai, K., Kapoor, S., Bhatia, R., Eds.; Springer: Cham, Switzerland, 2019 ; pp. 737-758. [CrossRef]

105. Jhaver, M.; Gupta, Y.; Mishra, A.K. Employee Turnover Prediction System. In Proceedings of the 4th International Conference on Information Systems and Computer Networks (ISCON), Mathura, India, 21-22 November 2019; pp. 391-394. [CrossRef]

106. Docebo. Your Friend: Artificial Intelligence in Corporate Training. Available online: https://www.docebo.com/learningnetwork/blog/corporate-training-ai/ (accessed on 13 August 2021).

107. Levtech Consulting. How Artificial Intelligence Is Benefiting Human Resources. Available online: https://www. levtechconsulting.com/how-artificial-intelligence-is-benefiting-human-resources/ (accessed on 13 August 2021).

108. Strammer. How Human Resources Can Benefit from Using AI. Available online: https://strammer.com/en/how-artificialintelligence-can-improve-the-job-of-human-resources / (accessed on 13 August 2021).

109. Jayasundara, C. Knowledge Management in Banking Industries: Uses and opportunities. J. Univ. Libr. Assoc. Sri Lanka 2008, 12, 68-84. [CrossRef]

110. Shawaqfeh, G.N.; Alqaied, B.A.; Jaradat, M.S. The impact of knowledge management on the performace of commercial banks' employees in Jordan (A field study on commercial banks' employees in IRBID Governorate of Jordan). Eur. J. Account. Audit. Financ. Res. 2019, 7, 1-16.

111. Lee, K.C.; Lee, S.; Kang, I.W. KMPI: Measuring knowledge management performance. Inf. Manag. 2005, 42, 469-482. [CrossRef]

112. Business Insider. The Future of Retail, Mobile, Online, and Digital-Only Banking Technology in 2021. Available online: https:/ / www.businessinsider.com/future-of-banking-technology (accessed on 14 August 2021). 